\title{
Staging an International Rock Festival in Alberta: A Documentary Reconstruction of Edmonton's Rock Cirkus
}

\author{
by Brock Silversides
}

\section{Abstract}

This paper, delivered in a shortened form at the CAML Conference in Calgary in June 2016, details the lead up to and production of the Edmonton Rock Cirkus in August 1979. It was the largest outdoor rock festival held in the Alberta capital up to that time, and was successfully staged in Commonwealth Stadium with a combination of top name international and Canadian acts, such as Peter Frampton, Heart, Streetheart, and Trooper. Using a combination of archival documents (primarily from the Martin Melhuish Fonds, held by Media Commons at the University of Toronto), contemporary press accounts, and reminiscences by organizers and performers, the groundbreaking festival's background, organization, logistics, economics, and physical production are reconstructed and discussed.

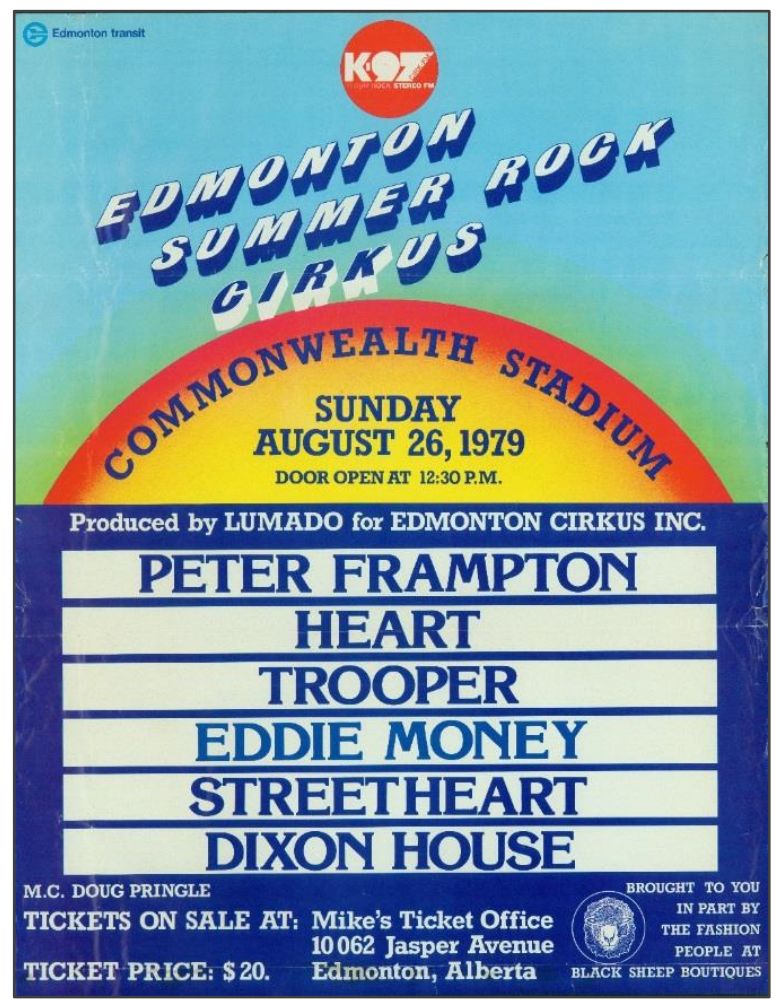

Poster for Edmonton Summer Rock Cirkus, August 1979 Courtesy of City of Edmonton Archives, EAP-53-1

Brock Silversides (brock.silversides@utoronto.ca) is Director of the University of Toronto Media Commons.

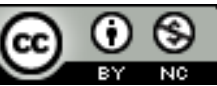

This work is licensed under a Creative Commons Attribution-NonCommercial 4.0 International License. 


\section{The Partners}

On August 26, 1979, Edmonton's Commonwealth Stadium played host to that city's first large-scale international rock festival. Christened "The Summer Rock Cirkus," it looms large in the memories of many Alberta music fans who came of age in that decade. The festival was organized, produced, and promoted by Lumado Enterprises Ltd. of Westmount, Quebec in conjunction with radio station K-97. At first glance, it makes little sense that a Quebec-based company would stage a rock festival 3,000 km to the west. But a seemingly random series of events, including radio programs, writing projects, consulting jobs, and fortuitous personal interactions, led inexorably to this result.

Lumado was comprised of three partners: Doug Pringle, Martin Melhuish and Lucien Richard. Pringle was born in Calcutta, the son of a British shipping executive, and was educated in South Africa, Belgium, and England. He moved to Boston in the mid-1960s, and was about to return to England when he visited Montreal. He was taken with the city, and on a whim, applied to Sir George Williams University (now Concordia). He was accepted, and immediately became involved in student activities, including "TV Sir George" and "Radio Sir George," where he quickly assumed the roles of announcer and program director.

With his in-depth knowledge of the current music scene, especially in Britain, and his brief student experience in broadcasting, Pringle was able to convince Geoff Stirling, the owner of the easy listening and money-losing CKGM-FM (later to be $\mathrm{CHOM}$ ), to let him program and host a four-hour show dedicated exclusively to full-on progressive rock. Starting in October 1969, it was immediately (and unexpectedly) successful, and within three months, the station had completely gone over to the newly labelled "Tribal Rock" format. Other young and hip disc jockeys were hired, and the traditional ways of doing things were thrown out the window. The DJs regularly played entire sides of albums instead of the two- to three-minute singles. They occasionally aired live performances by local bands such as Harmonium. They frequently did the between-song patter in both English and French, a practice that ended when some of the French language stations complained to the CRTC.

Most of the DJs were into spiritualism and meditation-thus the change of the station's call letters to incorporate the mantra "OM" after Pringle and Stirling returned from a pilgrimage to India. The DJs felt disdain for any form of authority, and the inmates were soon running the asylum. According to one article:

Pringle cheerfully pleads guilty to charges of self-indulgence, elitism and naivete. In 1969, he and his fellow DJs were totally ignorant of the radio business.... Pringle remembers an announcers' meeting to discuss whether to do time checks on CKGM-FM. The vote was no because "giving the time would put listeners into reality, and that was a bummer." ${ }^{1}$

In an odd reversal of roles, the DJ collective decided which advertisers they deemed acceptable for the station. There were numerous businesses clamouring to advertise on the new format, but few were

1. "Hippie Daze of the '60s Paved Way for Today's Yuppie Pros," The Gazette [Montreal, QC], Oct 21, 1989, H1. 
allowed to give the station their money. For example, the DJs did not want beer ads as "we were all smoking dope," ${ }^{2}$ and they did not want automobile ads because cars "polluted the atmosphere." ${ }^{3}$ Record stores were sometimes acceptable:

We had Sherman's, the record retailer, advertising with us at one point, that was until they put in a turnstile into their store. .. . This was cause for an immediate group meeting and, in the end, Sherman's ads got dropped because we felt this showed a lack of trust in their fellow man. ${ }^{4}$

With a business approach such as this, it goes without saying that the station was not as profitable as it could have been. Pringle was the ringleader for all these changes, and built up a large and dedicated following of listeners. Melhuish recalls Pringle's appeal:

He walked into Montreal, and he was God! Everybody considered him that. First of all, the English accent; the fact that he talked some French on the air, which they loved; the fact that he was almost like one of the guys that they adored-he actually worked with $\mathrm{T}$. Rex-and he just had charisma. Hair down to his ass-he was just a rock star. ${ }^{5}$

He also emceed concerts, and sat on juries for popular music competitions.

Pringle took a sabbatical in 1974 and 1975 and moved to London, UK. There he met members of the British broadcasting and musical fraternity, and even had a hand in co-producing several album tracks for Marc Bolan's T-Rex. Hoping England would be the promised land for progressive rock, he was quickly disillusioned. Instead, he found it completely overshadowed by trendy "Pop" music such as glitter rock (Gary Glitter, Slade), soccer rock (Bay City Rollers), and the beginnings of the dreaded disco. He returned to Montreal and CHOM, and wrote an article entitled "London Makes Montreal Look Good" for the Montreal Gazette in July 1975.

Pringle became even more convinced of the role of progressive rock in radio. He continued to program it, expanded his audience, and for the rest of the decade appeared to have the magic touch. Word leaked out about this new "guru" of the airwaves, and soon other Canadian broadcasters started to ask his advice on revamping their programming. It would not take long for Pringle to realize these informal consultations could be turned into further income.

Martin Melhuish came to the music industry from a different on-ramp. Born in Penzance, UK, his family immigrated to Toronto when he was a pre-teen. A budding guitarist, he played in several teenage bands such as Chateau Clique, and The Jeff Davis Highway (which of course had no one named Jeff Davis in it). Being slightly more ambitious and entrepreneurial than most his age, he also formed his own

2. Martin Melhuish, "A History of the Early Days at CHOM-FM," accessed May 2, 2016, www.alanrhodes.com/journals/appendix8.html.

3. Ibid.

4. Ibid.

5. Martin Melhuish, interview with author, March 20, 2015. 
management company and non-union booking agency called Britannia Enterprises in 1968. He was seventeen. ${ }^{6}$

Meluish was equally fascinated and frustrated by the Canadian media and its half-hearted, if not outright reluctant, coverage of popular music. But rather than just complain, he plunged in headfirst. In 1969 he started to acquire his reputation as a writer and reviewer for the underground newspaper Tribal Village. Taking the role of a young radio reporter, he covered the famous three-day Strawberry Fields Festival at Mosport Park outside Toronto in August 1970 for local stations CKEY and CKFH.

As he recalls:

I guess because I came from England and there was a lot of press out there like ... Melody Maker, Disc and Music Echo ... New Musical Express - I mean there were all of these amazing papers that wrote about nothing but popular music, and they were thick papers, and there wasn't one in Canada. ${ }^{7}$

There was one of course-RPM-but it contained solely Canadian content and was intended more for the Canadian music industry itself, not the general public. Melhuish continued to talk with people in the industry about the need for another music magazine. That led to the founding of Beetle magazine which featured both Canadian and international content for the general music-loving public. Melhuish:

That was interesting because I did the first one myself. . . I basically did it myself, and l'd never laid out a magazine, l'd never written an article, l'd never done anything. So the first one came out, and it looked like I didn't know what I was doing! ${ }^{8}$

Even so, it was considered significant enough to get a mention in Billboard in December 1970: "Canada now has its own national rock music newspaper, a bi-weekly, Beetle. The 16-page tabloid was unveiled this week by its founders, Archie Macdonell and Marty Melhuish. It is being distributed by Metro News."

His editorship led to several significant meetings:

Except for a couple of freelance people, it wasn't a paid gig. Even photographers . . . were coming and wanting to get involved - they just wanted to see their stuff in print. . . . Second issue ... that sort of worked out. We moved on ... did the third issue. This was where I met Ritchie Yorke and everything changed, because Ritchie was already on the international scene, he was already writing for all these New Musical Expresses. ${ }^{10}$

6. Martin Melhuish, interview with author, March 20, 2015.

7. Ibid.

8. Ibid.

9. "Beetle, Tabloid, Debuts in Canada," Billboard, December 19, 1970, 57.

10. Martin Melhuish, interview with author, March 20, 2015. 
Yorke was an important influence for Melhuish. Then Canada's foremost rock music writer, he was a regular correspondent for the major Canadian newspapers: the Globe and Mail, Montreal Star, Ottawa Journal, Toronto Telegram, and Winnipeg Free Press. As well, he wrote for numerous music magazines such as Melody Maker and New Musical Express in the UK, Zoo World, Hit Parader, and Rolling Stone in the United States and RPM in Canada. In 1972 Melhuish and Yorke decided to start their own magazine, which actually ended up as three, each more sophisticated and better funded than the last. First came Pop which only lasted two issues, then Grapevine which went for five issues, and finally Rainbow, which became another legendary but short-lived Canadian popular music magazine. Melhuish and Yorke were the co-editors and chief writers. They were, however, dependent on stringers from every region of Canada, so the content of Rainbow (subtitled "Canada's International Music Paper") was a dynamic mix of domestic and international music news.

In 1973 Melhuish moved into the big leagues of music journalism. He was first recruited by the New York City based Modern Stereo \& Hi Fi Guide as its Canadian contributor. In the fall of that year he replaced Yorke as the Canadian editor of, and main Canadian writer for Billboard, the most-respected music industry magazine. He contributed updates to the section "From the Music Capitals of the World" in every issue, and also wrote, edited, compiled, and promoted an annual insert on the state of Canadian music. Never one to enjoy an unoccupied moment, he also contributed occasional articles to $R P M$, and then agreed to become the Canadian editor for the Florida-based Zoo World, and the same for the Texas-based Performance.

Melhuish had always been interested in the Quebec rock music scene, especially since it had been woefully under-reported and under-appreciated in English Canada. His frequent trips to Montreal in search of music news, concerts and interviews made him appreciate its approach to arts and culture. Melhuish visited often, soaked in the good feelings, and needed little convincing to relocate in the fall of 1976:

I already had this sort of emotional connection to Montreal because it's a European city, and my wife and I had gone there a number of times ... so by 1976, it was a magic year, because the Olympics were in Montreal; the PQ got in, which I couldn't give a crap about, even though all the English people in Montreal were freaking out because they thought they were going to be hung from the posts! So I made the decision: I'm going to Montreal. And I started getting involved with all the music guys, like Bob Segarini. ${ }^{11}$

Melhuish continued his editorship of Billboard ("the Billboard office was in Thursday's Pub on Clinton Street!"), and further ingratiated himself into the Montreal music community. His house in Westmount became a communications centre, a studio, a party house, and a home away from home for musicians:

11. Martin Melhuish, interview with author, March 20, 2015. 
I had a house in Montreal - the infamous 7 Burton Avenue that was profiled in a two-page spread in the Montreal Gazette for the number of music industry figures that later became major executives or stars in the business that I had given refuge to over the years. ${ }^{12}$

Segarini remembered it well:

Martin's house in Montreal became a haven for musicians and musos, both local and touring, and a crash pad for the lazy, stoned, or destitute players that had a friend and fellow music lover in Marty, who took in everyone that needed a place to hang. Even a teenaged Erica Ehm spent time there before moving to Toronto and a still flourishing career in the entertainment business. ${ }^{13}$

Melhuish's first foray into book publishing occurred as chief writer on the project ultimately entitled Century of Sound, a commemorative book issued by Studio Un Deux Trois Limitée (a.k.a. Studio 123) to celebrate the 100th birthday of recorded sound. He took the next logical step into the ranks of music industry writers with his following project later that year. He begins the story:

Ritchie Yorke was still around . . . because we started talking about books, and Ritchie had a contact with Methuen Publications, and sold them on the idea basically of doing a brand called Rock Books. There was going to be Led Zeppelin, which he got exclusive access to. ... He called me one day and he said "You know, you were telling me about how Bruce [Allen] keeps calling you up and raising shit about how Canada doesn't give a shit about his band-what about a BTO book?" Okay, sure-called the band, no problem. Went out [to Vancouver] and got that together. ${ }^{14}$

With full support from Allen and Randy Bachman, Melhuish wrote Bachman Turner Overdrive: Rock is My Life, This Is My Song which was released in 1976. It established Canadian rock music as a topic worth taking seriously, and for Melhuish serendipitously established a new friendship. Methuen sent Yorke (with his The Led Zeppelin Biography) and Melhuish together on a national promotional book-signing tour, and as Melhuish recalls: "When Ritchie and I went and did a publicity tour, one of the stops was hometown Montreal, and that's where I met Doug [Pringle-who interviewed them on his CHOM show], and immediately we were like brothers-we had all of this stuff in common." ${ }^{15}$

Within months Melhuish and Pringle, the two hyperactive friends, founded a company called Primel Motivations to amalgamate and harness all their experience, knowledge and aspirations, and to engage in a plethora of music-related activities. Under the Primel umbrella they started to manage several

12. Martin Melhuish, e-mail message to author, July 16, 2012.

13. Bob Segarini, "The Story of the Segarini Band," accessed May 12, 2016, https://bobsegarini.wordpress.com/2012/08/27/segarini-the-story-of-segarini-band-chapter-one/.

14. Martin Melhuish, interview with author, March 20, 2015.

15. Ibid. 
Montreal artists, the first three being bilingual singer Nanette Workman (who had just issued her album Grits and Cornbread), Stanley Frank (who would shortly put out his first album S'cool Days), and The Pin Ups (featuring a young bass player and singer by the name of Sass Jordan).

They also produced commercials and jingles. Melhuish remembers that Pringle "had a company called Mediacollage [Studios], which was a little studio meant for doing jingles and ads for syndicated radio." ${ }^{16}$ The two expanded that by assembling radio specials on the histories of bands, written by Melhuish and hosted by Pringle. Two 1976 productions in particular were syndicated across the country-The April Wine Radio Special, and The Heart Radio Special.

And their most influential endeavor was about to be born: an ongoing radio program entitled The Pringle Program. It evolved from Pringle's local CKGM program into Canada's premiere showcase for progressive rock music. Not only did it become the program of choice for first airings of new musical releases, but it also featured exclusive interviews with the artists. It began in May of 1978 and quickly became a nationally syndicated weekly four-hour radio event. It was jointly written and assembled by the partners. Melhuish recalls:

It was just based on the fact that we were both music nuts, and he had a great voice and a great personality and the whole thing. And it was also a time when there was a dynamic going on between AM and FM. The AM stations were starting to get kicked a little bit by the FM stations who were programming all of this AOR [album-oriented rock] rock. So Doug figured there's got to be a dynamic here with the AM stations at least that may want this show. So we started talking about it around '77, and it took a long time to get together. ... We had to put a network together; we had to put the sponsors together. It was an expensive show to do. . . Album rock wasn't being done on AM. But the way it turned out, we actually picked up some FM stations too. ${ }^{17}$

Much of the interviewing and scripting was done in the home office on Burton Avenue in Montreal where the partners' record library was located, but the taping and final editing was generally done in Toronto at the CKFM Studio for St. Clair Productions, a subsidiary of Standard Broadcasting. Melhuish wrote an accompanying weekly syndicated "Pringle Program" column on general music news which was published by the Sun newspaper network. Even though they were convinced that this could be the answer to the contemporary lull in rock music broadcasting, the complete package succeeded beyond their wildest dreams. It exploded in popularity, and broadcasters scrambled to sign on. Billboard mentioned the show in an article "Canadian Radio: Professional, Successful and Profitable" published in January 1979:

In Toronto there is the "Pringle Program," hosted by Doug Pringle and produced by Martin Melhuish. The four hour mix of album cuts, artist interviews, record reviews, news and features

16. Martin Melhuish, interview with author, March 20, 2015.

17. Ibid. 
is carried by 54 stations nationally and the next step is to take it into the U.S., says executive producer Dave Hammond. ${ }^{18}$

The biggest selling point, and arguably the most popular segment of the program, was the interviews. Melhuish and Pringle thought it might raise their profile to go beyond Canada's borders to gather these interviews. Both attended the major 1978 rock festivals in the United Kingdom and the United States (notably California Jam II in March and Texxas Jam in July) as part of the press corps to do interviews. They then started to make monthly trips to the two countries to have in-depth talks with artists who they felt were on their wavelength. Some who appeared on the show in the incredible debut 1978-79 season included Alice Cooper, Atlanta Rhythm Section, Bee Gees, Kate Bush, Cheap Trick, Joe Cocker, Devo, Electric Light Orchestra, Fleetwood Mac, Foreigner, Marvin Gaye, Genesis, Jethro Tull, Journey, Kansas, Little River Band, Loggins \& Messina, Dave Mason, Meatloaf, Eddie Money, Moody Blues, The Motels, Ted Nugent, Pablo Cruise, Graham Parker, Pink Floyd, Suzi Quatro, Rush, Santana, The Sweet, Supertramp, Toto, Van Halen, Bob Welch, Gary Wright, as well as three Beatles: John Lennon, Ringo Starr, and Paul McCartney.

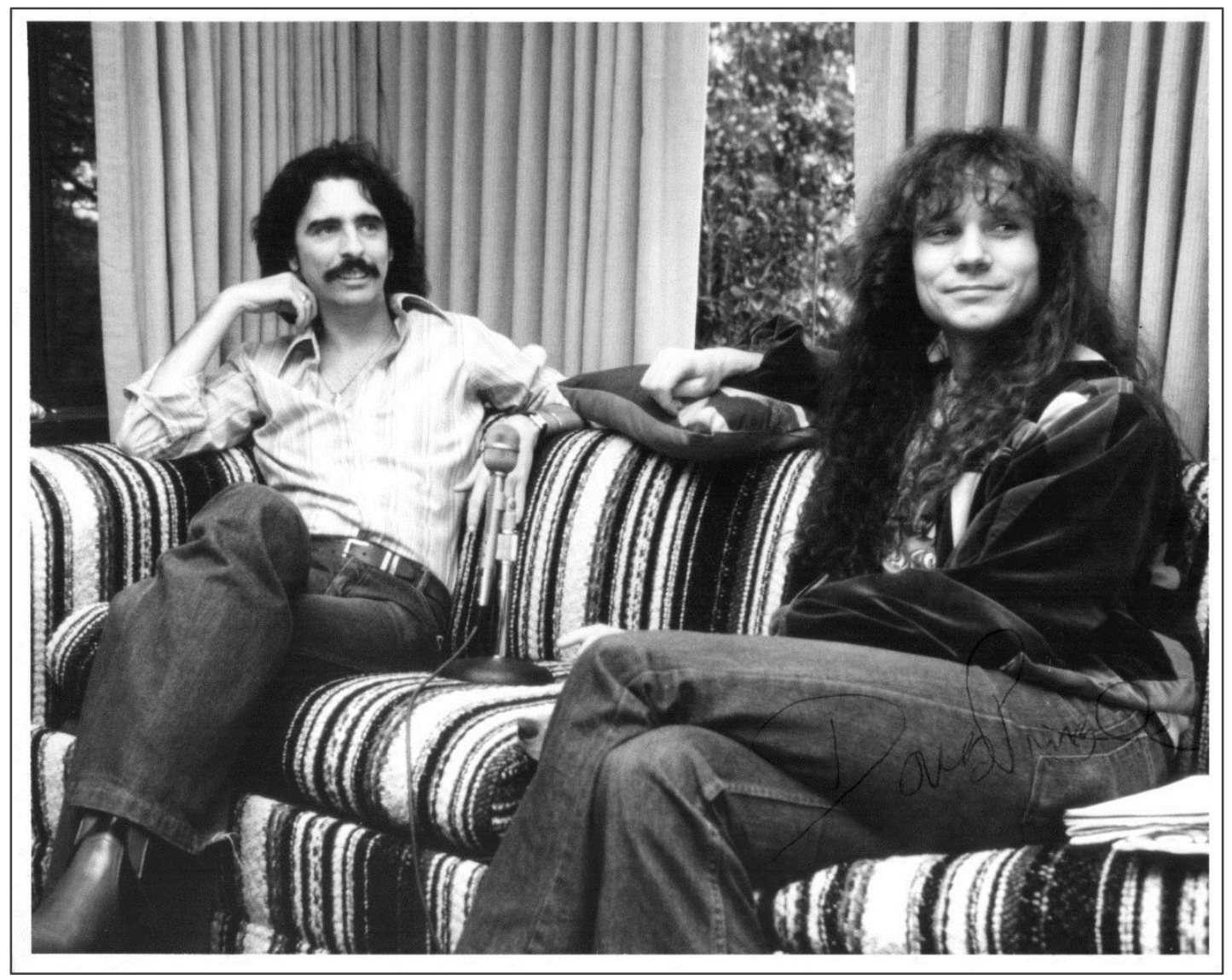

Doug Pringle (right) interviewing Alice Cooper for The Pringle Program, Spring 1979 Photo by Marty Melhuish

Courtesy of Martin Melhuish Fonds, Media Commons/University of Toronto

18. “Canadian Radio: Professional, Successful and Profitable,” Billboard, January 27, 1979, C32. 
Throughout this period Melhuish had also been establishing his own connections to Alberta. As far back as 1973 he was doing promotional work for The Stampeders. Billboard reported that "a special Stampeders World Tour newspaper has been prepared by Marty Melhuish and is being distributed to media."19 The twelve-page publication was given away at all points along what was, up to then, the biggest and longest tour by a Canadian band. Over 100,000 copies made their way into the hands of fans. ${ }^{20}$ Throughout the 1970 s Melhuish regularly reported on artists and musical events from Edmonton and Calgary. In early 1979 he assumed management duties with The Models, a new wave Edmonton band led by Peter Bodman and David Stahl. They released their debut album on Vera Cruz Records, working with legendary Alberta producer Wes Dakus, and were featured in several live radio broadcasts on the new station K-97.

The third member of the Lumado team was Lucien Richard. Richard was the business brain, the one who could tap into funding with some experience. Richard, originally from Trois-Rivières, started his career at the age of sixteen managing rock bands and comedy groups including Les Cyniques. He soon expanded to include promoting concerts in Quebec in the early 1970s with such artists as Tom Jones, Engelbert Humperdinck, and a number of European stars.

Richard co-founded the Vaudreuil West Holding Co. in 1974. The company did well, and by 1977 Richard, seen as one of the rising stars in Quebec business circles, had been asked to address the Chambre de commerce de Québec on his success, and was the subject of a glowing profile in the Montreal Gazette in February 1978. At this point Richard had no intention of going back into the financially inconsistent music business in any capacity.

\section{The Idea}

However, in early 1979 Richard was contacted by an anonymous Quebec financier who asked if he knew anyone who could organize a rock festival. He did indeed, and when he was informed that the silent partner was willing to front $\$ 650,000$, he quickly got in touch with Pringle.

Melhuish weaves the tale of the festival coming together:

One day, not long after The Pringle Program had taken to the air, we got a call from a financial guy by the name of Lucien Richard, who had known Doug during his CHOM days. He said he had a businessman who wanted to invest more than a half-million dollars in a rock concert at the Olympic Stadium in Montreal. Could we do it? Doug and I talked about it for about 10 seconds and decided it was well within our talents to do that ... . !21

As quickly as they said yes, sober second thought kicked in. They realized if they did this, they would be encroaching on someone else's turf. That person was promoter Donald Tarlton of Donald K. Donald who

19. "From the Music Capitals of the World," Billboard, February 24, 1973, 42.

20. Ritchie Yorke, "Daily Press Seen Hindering Artists," Billboard, July 14, 1973, 59.

21. Martin Melhuish, e-mail message to author, July 16, 2012. 
dominated the Montreal market. Melhuish: "We didn't feel comfortable stepping on his toes as we both knew him and considered him a friend." 22

Fate stepped in a week later:

We got another interesting call - this time from Edmonton from an AM radio station that was running The Pringle Program. They had just got an FM license for an album-oriented rock station but realized they didn't have anyone in the immediate organization that had the expertise to really make the format work. Somebody said: "what about that English guy we have on Sunday nights on our station?" They asked Pringle to come out to Edmonton, and when he returned he had the job as their consultant. He had also seen Commonwealth Stadium out there and called me to say that it might be just the place for a multi-artist concert though there had never been a concert of any kind at the venue. In our entrepreneurial minds we also realized that a concert like this would make a great launch for the station which had the call letters CIRK-FM. Wasn't much of a jump to come up with the name Edmonton Rock Cirkus for the proposed event. We spoke to Lucien - he spoke to the investor who was quite happy to take the show on the road. We started a company called Lumado (Lucien, Marty, Doug). ${ }^{23}$

The three partners in Lumado Enterprises appeared to have endless energy, an extensive insider knowledge of the music industry, friends and colleagues in every corner of the industry, an unarguable record of success at almost everything they had attempted, still a bit of idealism, and a willingness to take on anything. And unlike many promotion companies, they also had an eager silent partner with a large wallet (his identity remains a closely guarded secret to this day-all that Melhuish can recall is that he had some investments in the St. Hubert chicken restaurant chain).

It was proclaimed at the time that this was to be the first rock festival in Edmonton's history, but that is clearly not the case. Multi-band concerts and festivals had been a regular part of the Alberta capital's popular music scene for at least fifteen years. Examples are easy to find, especially in the 1960s, most organized by local promoter Benny Benjamin. For example, "The Holiday Hullabaloo," held December 29, 1965 at the Edmonton Gardens, featured the Kingbeez, Li'l Davey \& the Drastiks, The Lords, Tony Lewis \& the Birmingham V, Judy Singh, Bob Jones, Hans Staymer, and The Pussycats. A five band festival was held in Jasper Place Sports Centre in September 1966, showcasing local acts Wes Dakus \& The Rebels, The Nomads, Willie \& the Walkers, Barry Allen, and Calgary's Shades of Blonde. "Woodward's Salute to Youth" was held at the Northern Alberta Jubilee Auditorium on August 25, 1967, and featured Dino, Desi \& Billy, The Guess Who, Willie \& the Walkers, and Barry Allen \& The Southbound Freeway. On March 3, 1968, Edmonton Gardens hosted a rave-up with The Who, local bands Warp Factor, The Heat, The Young Ones, Willie \& the Walkers, and Winnipeg's Sugar 'n Spice.

22. Martin Melhuish, e-mail message to author, July 16, 2012.

23. Ibid. 
The largest and most memorable festival was a two-day outdoor concert held in Renfrew Park (a baseball stadium) on July 7-8, 1968. It was called The Orange County Pop Festival for a number of California bands that were to have headlined, including Country Joe \& The Fish. None of them made it over the border (recreational drugs may have been involved), and all the final talent was Canadian. The festival, organized by Benjamin and Wes Dakus, still had a strong lineup and went ahead anyway. The acts included Vancouver's Tom Northcott and the Syndicate, My Indole Ring, and Papa Bear's Medicine Band; a lone Saskatchewan representative called The Mozart Group; and a palette of local bands such as Barry Allen and Purple Haze, The Young Ones, Shame Tree, The Heat, St. James Infirmary, Warp Factor, International Dateline, The Circus, Martha Strange, The Graeme Waifers, and the Harrad Experiment.

A second Orange County Pop Festival was held the following July and included Toronto's Buckstone Hardware; two Vancouver bands, Jason Hoover and The Fox; two Calgary bands, Happy Feeling and Gainsborough Gallery; and three Edmonton bands, Russell Thornberry with Denim \& Lace, Coloured Rain, and the Angus Park Blues Band. There was no similar event in the 1970s that had lived up to the Orange County festivals, and that may be the cause for the festival amnesia.

\section{The Partner and the Venue}

A major partner in the upcoming festival was the radio station CIRK-FM, better known as K-97. It was the FM affiliate of the long-established AM station CJCA. Although it had existed since 1975 as CJCA-FM, it had recently re-branded itself as AOR (album-oriented rock) to appeal to both a younger and wider audience. The station was managed by Terry Strain, and the first program director was Neil Edwards. The original disk jockeys included Bruce Kenyon (also music director), Gerry Siemens, Kelly Huxtable, Jim Hees, Joanne Wilson, Ted Kennedy, and Dave Korchin. Under its new moniker it returned to the airwaves on May 4th, 1979. It was given full promotion in Billboard:

The Midwestern Canadian city, long one of Canada's top concert and album buying markets, now has its own AOR station. ... The new format debuted with "It's Only Rock and Roll, But I Like It" by the Rolling Stones. One of the first moves the station made was to hire Doug Pringle, thought by many to be Canada's top AOR programmer and personality, as a full time consultant. ... The station plans to be presenting major rock shows in the market. To kick off the format, 20 billboards were rented and newspaper advertising has been utilized. ${ }^{24}$

24. “Edmonton Gets New AOR Outlet Known as K-97," Billboard, June 30, 1979, 18. 


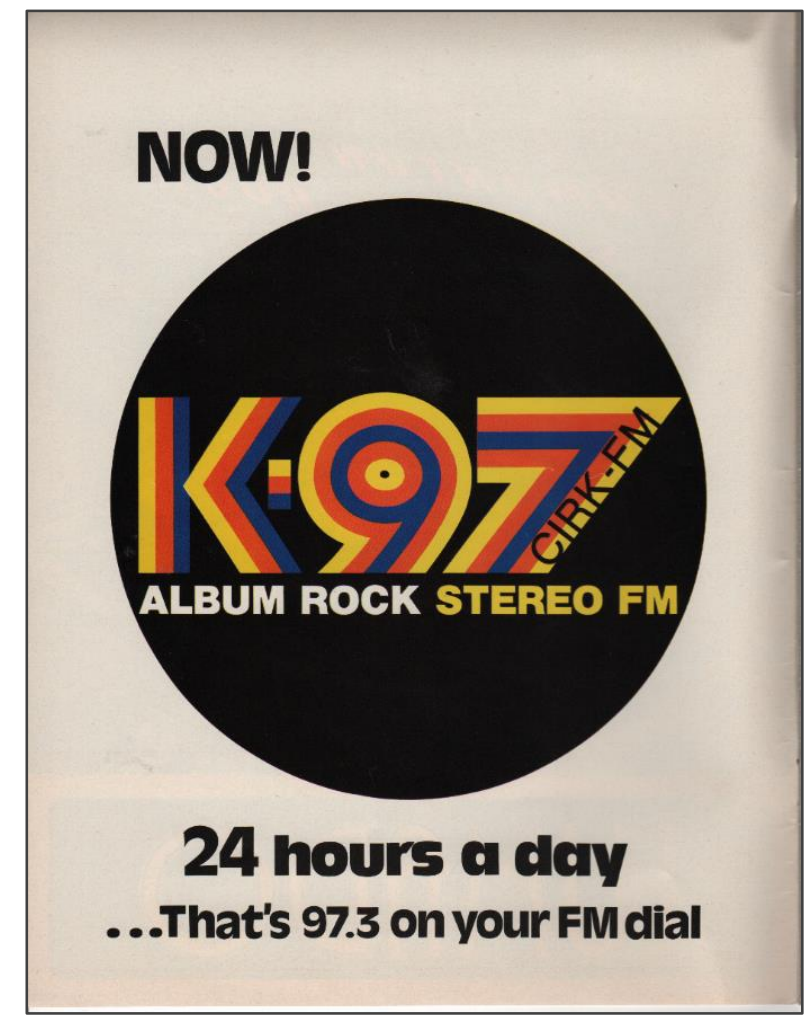

Advertisement for K-97 radio station, August 1979

From Edmonton Rock Cirkus Official Souvenir Program

K-97 hit the ground running. It aired live broadcasts of local bands from the Riviera Rock Room. It also sponsored, assembled, and pressed the annual "home-grown" albums that spotlighted local talent. And of course it aired the much-respected Pringle Program. But it was still the upstart, and needed to make a name for itself. Recalls Bruce Kenyon:

We went on the air in May or June with none of us at the station really having a clue as to running a rock station. At the time we were running the syndicated Pringle program, and Doug being the seasoned pro he was, we hired him as a consultant. Best move we ever made. He righted the ship and pointed us in the right direction. With our first ratings book we had an audience of about 30 thousand, and our main competitor was CHED whose audience was over 400 thousand ... a a huge uphill battle. Pringle felt that we needed to make as big an impact as we could, and since we had a limited promo budget, the idea of the Rock Cirkus came about. ${ }^{25}$

Pringle, as a consultant and advisor, quickly built up a solid relationship with the management and staff, and naturally wanted them to succeed. The joint vision then included the biggest rock show ever held in the Alberta capital, along with the biggest, loudest marketing campaign ever mounted by an Edmonton radio station. By the first week of June 1979, the partnership between Lumado and K-97 was sealed and K-97 initiated the promotional efforts.

25. Bruce Kenyon, e-mail message to author, June 182012. 
Lumado and K-97 knew they had to have a roomy venue to properly carry out the event they envisioned. There were five possibilities open to them: the Jubilee Auditorium, the Kinsmen Field House, Northlands Coliseum, Clarke Stadium, and Commonwealth Stadium. The Jubilee Auditorium, built in 1955, was undoubtedly the classiest and most comfortable of the venues, but only had a seating capacity of 2,500. This was a mere drop in the bucket of the audience they were envisioning. The Kinsmen Field House, located in the river valley, was opened in 1968 and was the venue for many of Edmonton's most memorable rock concerts such as Led Zeppelin (1969), Vanilla Fudge (1969), Frank Zappa (1971), Painter (1972), Kiss (1974), Queen (1975) and Rush (1977). However, it was designed as a multi-purpose room, and its acoustics left many critics and audiences howling about the unsatisfactory sound. Next was Northlands Coliseum (later renamed the Skyreach Centre, and currently Rexall Place). It was a 16,000 seat hockey arena that was built in 1974 for the Edmonton Oilers and the lacrosse team, the Edmonton Rush. While it had a proven record for rock concerts such as The Who (1976), Rush (1978) and Rod Stewart, Jethro Tull and Van Halen (1979), it still was too small for the event Lumado and K-97 had in mind.

The outdoors then beckoned: there was Clarke Stadium, built in 1938, with a seating capacity of 20,000. While it had charm, it had certainly seen better days. Edmonton's newest big-crowd venue, Commonwealth Stadium, finally became the logical choice. It had been constructed the year before, just in time for the opening of the Commonwealth Games in August 1978. Located in the east central neighbourhood of Norwood at the corner of 112 Street and Stadium Road, it was owned and operated by the City of Edmonton. Upon completion of the Commonwealth Games, it immediately replaced Clarke Stadium as the home of the Edmonton Eskimos. With a fixed seating capacity of 39,000 (and up to another 4,000 on the stadium floor), a $3 \frac{1}{2} 2$-storey scoreboard, a glass-fronted Communications Centre for press, and easy access to the LRT subway, it was second only to Montreal's Olympic Stadium as a Canadian sports venue. The choice could not have been clearer.

The Rock Cirkus was to be the first music festival held in Commonwealth Stadium, and it was by no means a given that the event would be acceptable to Commonwealth management. Lumado started negotiations early with the venue, and immediately realized they were neither wanted nor trusted. Recalls Melhuish:

This was the home of the Edmonton Eskimos and coach Hugh Campbell was not interested in having a bunch of rock ' $n$ ' rollers anywhere near his playing field. We made the point that it was a public space and could be used by anyone. We realized we had some work to do, so Doug and I headed out to Edmonton with our assistant for what might have been about a month. We rented a house and we started to work the media to get the public on our side. I made a side trip to Calgary, which we knew was going to be an important market for us if this came together. Believe me, the folks out west were none too pleased seeing an organization come in from Quebec to promote rock concerts. The press could be fairly brutal . . . ${ }^{26}$

26. Martin Melhuish, e-mail message to author, July 16, 2012. 
An internal Lumado report was compiled detailing various aspects of the venture on June 6, 1979, and a copy can be found in Melhuish's archive. The pages dealing with Commonwealth Stadium give interesting information on what the promoters had to deal with. First, the administration at Commonwealth did not initially feel comfortable with an open-ended schedule: "Mike Kelly seemed to be very retiscent [sic] about holding a festival as compared to a concert. He said that he wouldn't like to see the "concert" run more than three hours. Obviously that is something that is going to need serious discussion." 27

Then under the cost section were the possible financial arrangements with Commonwealth Stadium:

- The cost of the stadium based on 55,000 (the maximum they will allow) is their cost $(\$ 75,000)$ plus $\$ 10,000$ or $15 \%$, whichever is greater.

- They require $\$ 2,500$ deposit 90 days before the concert and the balance of the deposit 60 days before the concert date. This is obviously flexible.

- Based on 35,000 people at the stadium, the cost to us is their cost $(\$ 50,000)$ plus $\$ 10,000$ or $15 \%$ whichever is greater. ${ }^{28}$

The stadium's responsibilities included the ushers, police and other security, liaison with Edmonton transit, the stadium clean-up, and utilities. The report conjectured that "overtime payments and the building of steps to and from the infield is not included in the price but I think is their responsibility. We should get that clarified. Our responsibilities are a tarp for the field, security fencing at the stage and insurance as well as the stage, lights and sound."29

Finally, the stages of approval were spelled out:
A) We have to get approval from the Department of Parks and Recreation for the type of event and date
B) The contract has to be recommended to the Commission Board
C) City Council Approval
D) Finalize negotiations ${ }^{30}$

The Lumado team got to work immediately on several fronts. Firstly Melhuish and Pringle set up offices in the Edmonton Plaza Hotel where they typically worked twelve-hour days. As they would end up living in the city for the next two months, they arranged to produce The Pringle Program in Edmonton for the duration. Next was the selection of talent. There was an amazing array of bands and artists touring North America that summer, and the team wanted to get at least two top acts supplemented by some mid-level acts and one or two local bands as well.

27. “Edmonton Rock Cirkus - Initial Report, June 6, 1979,” Martin Melhuish Fonds, \#2013.005, Media Commons, University of Toronto Library.

28. Ibid.

29. Ibid.

30. Ibid. 


\section{The Lineup}

The previously mentioned internal report of June 6, 1979 noted that the Beach Boys were available. However, since they asked up-front for $\$ 150,000$, they were quickly off the table. The other bands mentioned in this first go-round included Van Halen, Dire Straits, Rickie Lee Jones, Goddo, and Dual Exhaust. Another undated projected budget document in Melhuish's archive incorporates potential payments to Alice Cooper and to the Atlanta Rhythm Section, so they were obviously strong candidates during the selection process.

Lumado knew they needed at least one international act to headline. Both Pringle and Melhuish came to that decision quickly: they wanted British singer and guitarist Peter Frampton. His reputation was huge, and he was already touring the United States that summer. Melhuish explains:

Peter Frampton had done his Frampton Comes Alive show everywhere but we knew he hadn't done it in Edmonton. That's what put him at the top of our list. We actually hadn't met him prior to the concert but a good friend of both Doug and mine was Quebec singing star Nanette Workman. Doug managed her for a while, and she lived with me at 7 Burton for a time. She and Frampton had both worked with French star Johnny Halliday and they had had a brief fling. Nanette's life is a movie... ${ }^{31}$

Frampton had star power- of that they were in no doubt. He had started his career with The Herd in 1967. He was always a "pretty-boy," and indeed had been given the title of "Face of '68" by the teen magazine Rave. It was the kind of notoriety he did not appreciate, as it made his guitar prowess seem somewhat less than serious. Therefore in early 1969 he co-founded the down and dirty rock band Humble Pie with Steve Marriott. They issued a number of top-selling albums, and were known especially for their Performance: Rockin' the Fillmore, which had gone gold in the United Kingdom, the United States and Canada. Personality clashes led to Frampton leaving Humble Pie in 1971. For several years he stayed under the radar, writing and recording as a solo artist. But in 1976 he put out another monster double live LP entitled Frampton Comes Alive. It quickly topped the RPM charts in Canada as well as the Billboard chart in the United States for 10 weeks (and stayed on that chart for an unheard-of 97 weeks). It sold six million copies in the United States that year and was voted album of the year by Rolling Stone readers. By 1984 it had sold six times platinum.

It was an incredibly hard achievement to follow, and Frampton did not even try. His next album I'm In You (1977), while reaching platinum status, was generally considered a serious stumble. Then in 1978 he starred in the Robert Stigwood film Sgt. Pepper's Lonely Hearts Club Band with the brothers Gibb. For many of his long-term fans, it was the loss of his last shreds of credibility. Just after its release, Frampton was removed from the public eye when he was involved in a serious car accident in the Bahamas. He broke an arm, and took half a year to recover, during which he wrote very little. The spring of 1979 then

31. Martin Melhuish, e-mail message to author, July 17, 2012. 
saw him return to the recording studio with the less-than-stellar LP Where I Should Be, and he slowly eased back into the world of touring. By August he was travelling around the southern United States.

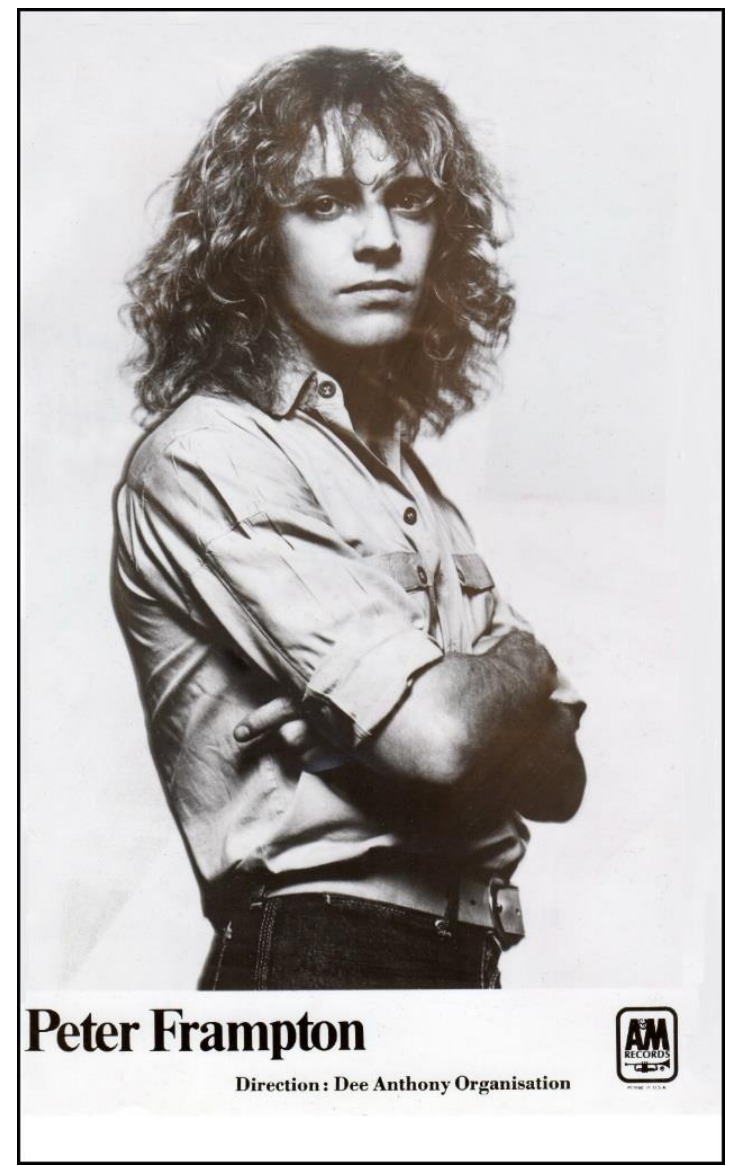

Peter Frampton promotional portrait, 1979

A\&M Records

Author's collection

As the potential cornerstone act, the members of Lumado were willing to do almost anything to attract him. They offered to pay him more than any other band on the bill, and as an act of good faith, they were also prepared to offer him a degree of creative control over which other bands would appear and over the day's sequencing. A copy of his contract is still extant, and it gives a clear idea of the concerns (and mutual distrust) between artists, managers, and promoters. Dated July 19th, the primary document confirmed a payment of $\$ 100,000$ (US currency), and if more than 55,000 tickets sold he would get 25 cents of every dollar earned "after $\$ 1,100,000$." As well it guaranteed Frampton "sole star billing," "choice of playing positions," and "final approval of all supporting acts." 32 There are also two separate and very wordy riders, one five pages and the other six pages in length, which give a fascinating insight into how tour agreements were negotiated in the 1970s.

32. "Peter Frampton Contract - Rock Cirkus, 19 July 1979," Martin Melhuish Fonds, \#2013.005, Media Commons, University of Toronto Library. 
The first rider agreed that Frampton would be paid $50 \%$ of his fee in advance, that the artist receive "adequate private bathrooms and dressing room facilities, all dressing rooms to be air-conditioned," "one tuning room with 100 volts A.C. outlets and one hospitality room." There was a prohibition against any filming, recording, or broadcasting of Frampton's performance without the express written permission of the artist. In the event that this was done accidentally or otherwise, the producers had to agree to immediately pay Frampton $\$ 50,000$ in damages. ${ }^{33}$

Frampton was given "the first right of set up for all instruments and properties used in the presentation" and the guarantee that "aforesaid instruments and properties shall not be moved, relocated and/or be used by any other than road/production manager of the vendor." In addition, Lumado agreed "to undertake the affirmative obligation to use its best effort to prevent the sale of unauthorized merchandise in the immediate vicinity of the site of the performance." ${ }^{34}$

The second rider, called the "Indoor Technical Rider," spelled out the stage and sound requirements and technical specs. Then there were specific demands for the site preparation including access, security, and communications. And, as is frequently the subject of much-deserved mockery in touring band riders, there were the hospitality room demands. For Frampton's band and friends, the rider demanded:

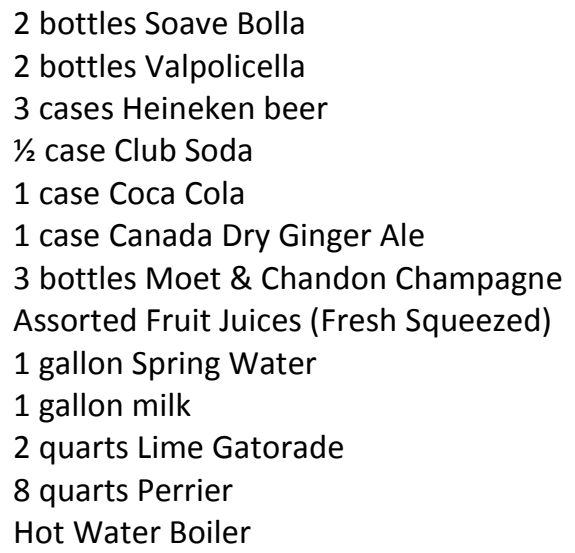

Earl Grey Tea Honey/Lemons/Brown Sugar 1 Salad Bowl (for 15 people) 1 Fruit Bowl (for 15 people) 1 Cheese Tray with Crackers (for 15 people) 1 tray Fresh white turkey meat 2 loaves whole wheat bread Butter/Mayonnaise/Mustard/Salt/Pepper/etc. Hot Cups Cutlery 24 bath size towels IceCorkscrews

And for his road crew:

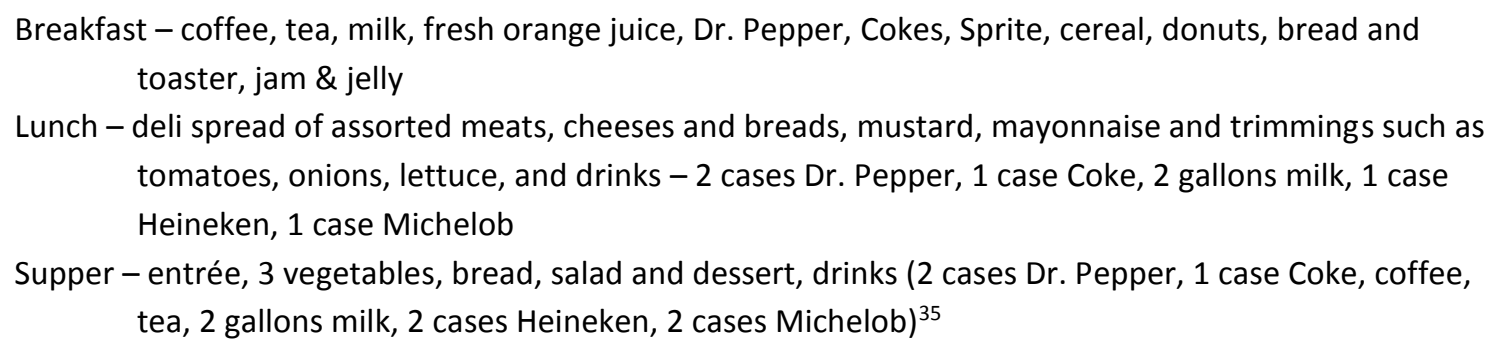

33. "Peter Frampton Contract - Rock Cirkus, 19 July 1979," Martin Melhuish Fonds, \#2013.005, Media Commons, University of Toronto Library.

34. Ibid.

35. Ibid. 
One of the first Canadian acts to sign on was the Winnipeg-based Streetheart. A merger of two talented but underrated prairie bands, Witness and the Great Canadian River Race, they were originally fronted by vocalist Kenny Shields and guitarist Paul Dean, and included Daryl Gutheil (keyboards), Matthew Frenette (drums) and Ken "Spider" Sinnaeve (bass). They had begun their rise to prominence in 1977. In 1978 they released a stunning debut album Meanwhile Back in Paris. The momentum faltered somewhat when Dean and the band parted company in September 1978. However they replaced him with John Hannah, recorded the highly anticipated follow-up LP Under Heaven Over Hell (with the wellknown single "Hollywood"), and kept going. Their first album subsequently went gold, and early in the new year, Streetheart took part in one of the first Canadian simulcasts when their February 23 concert at Toronto's famed El Mocambo was aired by both CITY-TV and CHUM-FM.

The band had been touring for most of 1979: a prairie tour in March and April, their first Atlantic Canadian tour in May and June, and again across the prairies leading into Ontario and Quebec in July and August. They had played at the Triple Tripper Rock Concert in Athabasca, Alberta, on Canada Day, but had made their biggest splash at a Montreal nightclub, Le Pretzel enchainé, on August 21 and 22, and at Ivor Wynn Stadium in Hamilton on the 24th. They were in top form, battle-hardened and musically tight, and they already had a core group of fans waiting for them in Edmonton. Journal writer Graham Hicks was in their corner: "Streetheart is a nitty-gritty all-out rock and roll band. One has to be partial to the band, as it burst out of the Western Canadian rock circuit less than a year ago. Streetheart is working at a grueling pace, touring every two-horse town in Canada, to solidify its reputation." ${ }^{36}$

Trooper were next to come on board. This Vancouver-based band, led by vocalist Ra McGuire and guitarist Brian "Smitty" Smith, had started as the obscure Winter's Green in 1967. In the early 1970s they had changed their name to Applejack, and their energetic stage show (as well as promotion efforts by their manager Sam Feldman) brought them renown on the West Coast. They caught the attention of Randy Bachman, who signed them to his Legend Records label in 1975, produced their first LP, and convinced them to change their name yet again to Trooper. The other band members included Tommy Stewart (drums), Frank Ludwig (keyboards), and Doni Underhill (bass).

1979 was a big year for the band. In June they won a Juno for "Group of the Year." They released two albums that year as well, their fifth studio album entitled Flying Colours, much of which had been recorded in Edmonton's Sundown Studios. It contained two big hits: "3 Dressed Up as a 9" and "Janine," which would go on to be their biggest chart hit ever. They had also just released their greatest hits album Hot Shots prior to the festival, and it was breaking big. Even so, there was discord in the Trooper camp, and it turns out they were not an original choice for Lumado. Recalls McGuire:

The Runaways were supposed to have our slot but they cancelled at the last minute. The promoters (Marty and Doug) called Bruce Allen Talent in a panic . . . looking for someone to fill in. Sam brokered the best fee we'd been paid to date for the slot. ${ }^{37}$

36. Graham Hicks, "All Systems Are Go for the Rock and Roll Cirkus," Edmonton Journal, August 22, 1979, G8. 37. Ra McGuire, e-mail message to author, July 11, 2012. 
Heart followed shortly after. They were formed in 1975 and led by the Wilson sisters Ann (vocals) and Nancy (guitar). The other members were Roger Fisher (guitar), Howard Leese (guitar), Steve Fossen (bass), and Michael Desrosier (drums). Although all the members were from the United States, they had moved to Vancouver and recorded their first album Dreamboat Annie for the Canadian label Mushroom Records. From this, two monster singles hit the radio waves: "Dreamboat Annie" and "Crazy on You". Their refreshing combination of hard rock, folk and heavy metal appealed to both teenage boys and girls. They released their second LP Little Queen in 1977 which featured the dynamic singles "Barracuda" and "Heartless."

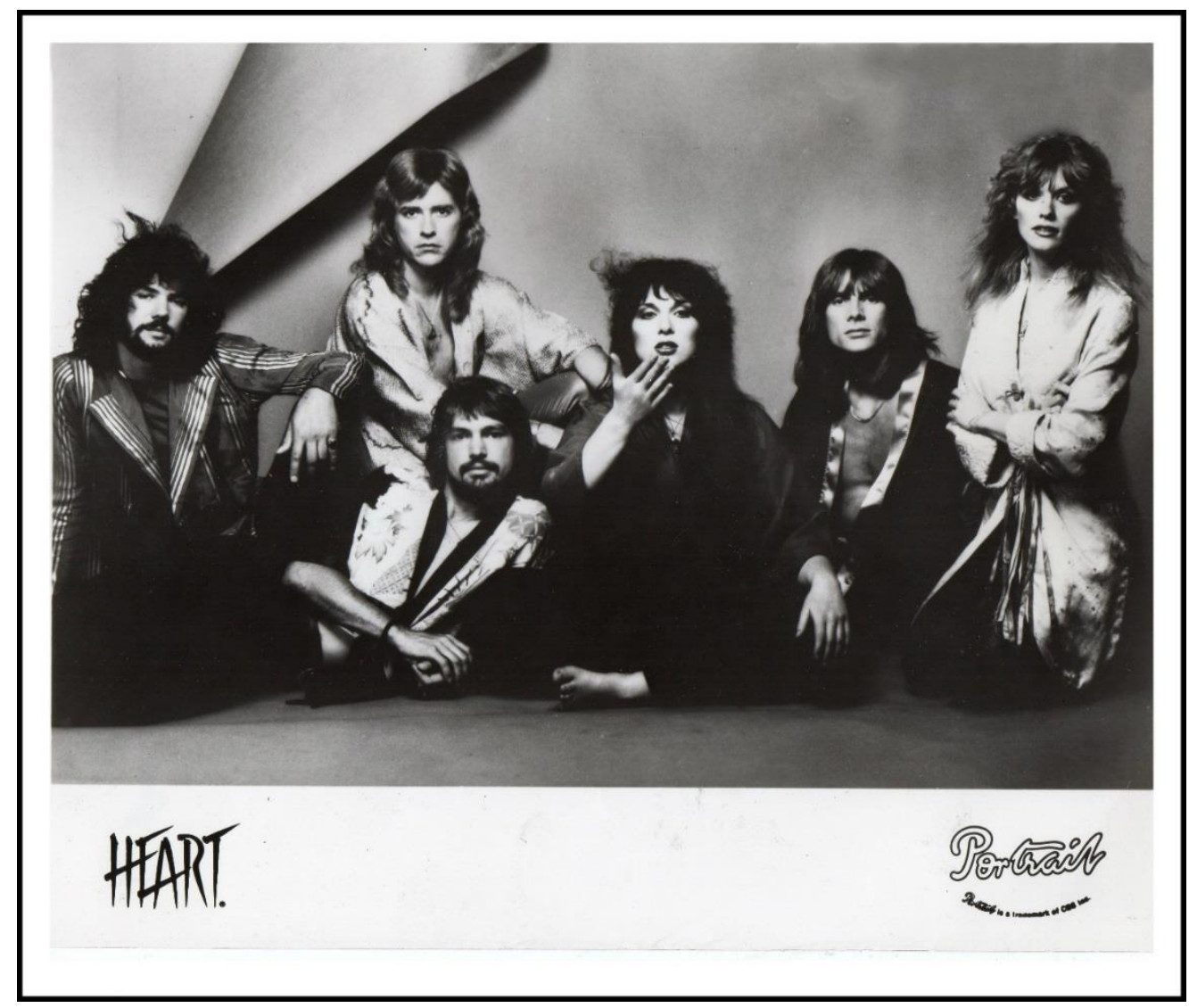

Heart promotional group portrait, 1979

Portrait Records

Author's collection

Two Heart albums came out in 1978: Magazine at the beginning of the year with their old label Mushroom Records, and Dog and Butterfly at the end with their new label Portrait Records. Heart was at the tail end of their almost six-month long, seventy-seven city "Dog and Butterfly" Tour when the Rock Cirkus offer was made to them. June had seen them in Little Rock, Tulsa, Fort Worth ("Texas Music Festival"), New Orleans, and Denver. At the beginning of August they had appeared at the "Japan Jam" in Kanagawa. Heart was surprisingly easy to land. They were going to be in the neighbourhood anyway with a concert at Calgary's Stampede Corral on August 23rd, and had a tentative date at Edmonton's Northlands Coliseum the following evening. 
Their Calgary concert left mixed feelings. Herald writer Brian Brennan was impressed with segments:

The band cooked with fire, as one of their recent songs puts it, for about the first half hour or so. Ann Wilson, squealing about "kicking the role thing," went for the collective male jugular with a succession of fiercely melodramatic rockers - High Time, Heartless, Devil Delight and Straight On, which has to be the best pop-rock tune she has recorded in four years. Then everything died for another half an hour while the band meandered through a turgid selection of ballads from the Butterly [sic] side of their yin-yang Dog and Butterfly album. However a driving rocker called Crazy On You woke the house up in time for the customary standing ovation. ${ }^{38}$

But ultimately he came to the conclusion that "Led Zeppelin leftovers, mushy folkie fare and the shrieking voice of lead singer Ann Wilson are not quite enough to make for a performance that nourishes the spirit." 39

Heart's manager, Ken Kinnear, recommended another band from his "stable" for the Cirkus. Melhuish remembers: "Heart was a natural, because Doug and I knew them. So it was just a matter of dealing with their manager, and Ken said, "Sure, will you also take the Dixon House Band?" 40 The Dixon House Band originated in Vancouver in the early 1970s, and also had ties to Seattle and Heart. The original lineup consisted of Edward Dixon House (keyboards and vocals), Chuck Gardner (guitar), James Kenfield (bass), and Fred Zeufeldt (drums). Producer Mike Flicker (also Heart's producer) came across guitarist Chrissy Shefts in a Seattle cover band, and convinced the band that they needed her hot guitar style and visual impact.

With their new recruit, the Dixon House Band released their first, and what was to be their only album called Fighting Alone in 1979. It was somewhat grandiose, even pretentious, concept material. As one profile put it:

Dixon's writing all has a point to it. The world of the crusader, of love and loyalty and human endeavor despite its cruelty and suffering of life, is constantly mingling in the musical world of Dixon House, affirming his quest for something beyond human existence. Dixon himself explains “. . I've always been interested in art and history and wanted to do something that had stability to it. History is a foundation everybody can relate to. By interweaving that with exploring relationships, we wanted to transcend time. And music is our icon." 41

In addition the band had recently supported Heart on one leg of their 1979 American tour, and opened for them at their Calgary date on August 23rd.

38. Brian Brennan, "Heart Concert Could Do Better Than Zeppelin Leftovers, Mushy Fare, Shrieks," Calgary Herald, August 23, 1979, A21.

39. Ibid.

40. Martin Melhuish, interview with author, March 20, 2015.

41. "Dixon House Band," Rock Cirkus Souvenir Program, unpaginated. 
Although Melhuish does not recall Frampton personally using his creative veto at any time, they still had to go through Frampton's agency with their final selections before they could conclude the deal. Paul Smith of Premier Talent sent a telegram to Melhuish on July 26th emphasizing:

Please remember that there is no firm contract until the other acts have been submitted to and approved by Peter Frampton therefore you may not, repeat may not advertise or promote the proposed date until you have written approval from Premier Talent of Peter Frampton's contractual agreement. ${ }^{42}$

On Wednesday August 1st, the three Lumado partners staged the first official press conference to announce the tentative lineup and ticket prices. One reporter cornered Richard:

Today's announcement follows seven weeks of negotiations and the signing of a 27-page contract with the city for rental of the stadium. All details have been worked out, says Richard. "It shouldn't be that different from 42,000 fans at a football game." Lumado will open a permanent office in Edmonton, Richard says. "Any money we might make will stay in the province. We will recycle it into more productions." It is going to cost $\$ 750,000$ to produce, and will go on, rain or shine. ${ }^{43}$

The Edmonton Sun got the news out immediately. That day Pat Burns announced in his column "Periscope" under the heading "Send in the Clowns" that his readers should "get ready for the Edmonton Summer Rock n' Roll CIRKus. .. . Those cute people down at CJCA have come up with an interesting name for their big K-97 music stomp next month - can we expect three rings of spills and chills?" 44 He then goes on to report that "they'll be announcing today that Peter Frampton has been confirmed, along with Heart. Trooper and Streetheart are likely to sign soon, and Prism is a remote possibility." He reported that Heart cancelled a scheduled date at the Coliseum to make the Cirkus on the 26th, and ended with the less-than-enthusiastic "That's it . . you can wake up now."45

K-97 and Lumado published the official lineup in their ad in the Sun on August 3. The next-to-final lineup, then (in the order in which they would appear), was The Dixon House Band, Streetheart, Peter Frampton, Trooper, and closing the show, Heart. The promoters knew they still were adding one last act, but left that as a question mark teaser. The ticket sales were given over exclusively to Mike's Ticket Office (10062 Jasper Avenue) and their price was fixed at \$20 per.

Several members of the local press were initially skeptical of both Lumado and of the musical lineup. Graham Hicks of The Journal voiced the first doubts:

42. Telegram - Paul Smith (Premier Talent) to Martin Melhuish (Lumado), July 26, 1979, Martin Melhuish Fonds, \#2013.005, Media Commons, University of Toronto Library.

43. "Peter Frampton Coming," Edmonton Journal, August 1, 1979, D15.

44. Pat Burns, "Periscope," Edmonton Sun, August 1, 1979, 12.

45. Ibid. 
Putting on first-rate rock and roll shows is a demanding, complicated, professional business. Alberta only has two promoters working in the province that have proved to be consistently good at presenting their acts - Vancouver's Perryscope Productions, and Calgary's Brimstone. MGM and Gold and Gold Productions are reasonable. White Rose Productions used to handle mid-sized acts, but haven't done much of late. Yardbird Productions in Edmonton is treated with respect by everybody in and out of the business. Nobody else has the track records of the above companies. And when greedy businessmen get into rock concerts, beware! They spoil it for everybody else. ${ }^{46}$

He went on to put the spotlight on Lumado:

Speaking of festivals, a couple of eastern professionals are moving into Edmonton for the first big outdoor show at the Commonwealth Stadium, Aug. 25. Lucien Richard has done many shows in Montreal, and is backed by rock media types Doug Pringle and Martin Melhuish. Funny ... I've always thought those that made their living writing about rock and roll shouldn't have money or time invested in promoting groups or concerts. It's called conflict of interest. ${ }^{47}$

James Adams, also of the Journal, expressed doubts, but his were on the choice of acts:

Couldn't they get anyone more exciting? That was the reaction [on] Wednesday to the announcement that Peter Frampton and Heart would head the K-97 Summer Rock Cirkus Aug. 26. The day-long concert, set for the fabulous Commonwealth Stadium, marks the first big promotional gambit for $\mathrm{CIRK}$, which has been blasting album-oriented rock over the FM airwaves for three months now. ... right now there's a general feeling among rock cognoscenti that Frampton is essentially a journeyman rocker, not a major artist, someone who happened to be in the right place at a particular low point in rock history. Will the kids, then, pay $\$ 20$ each for the thrill of hearing Mr. F. play the ditties from his bestselling record? Or will they shun "the pretty pop rocker" as a has-been. ${ }^{48}$

He then voiced his hesitations about the event itself:

Another up-in-the-air factor has to do with the entire rock festival format. To date, outdoor gatherings in Alberta have not been especially successful, the recent Athabasca Jam being the classic example. Can 55,000 rockers be coaxed into an enclosed-yet-exposed environment that will be patrolled by a sizable corps of Edmonton's finest? Doug Pringle, pop columnist, syndicated disc jockey, K-97 consultant and one of the Cirkus organizers, thinks everything is going to be all right. But then he has to: after all by 12:01 a.m. Aug. 27 he and his partners will

46. Graham Hicks, unidentified article in Martin Melhuish Fonds, \#2013.005, Media Commons, University of Toronto Library.

47. Ibid.

48. James Adams, "James Adams on Television and Radio," Edmonton Journal, August 3, 1979, I-7. 
have spent between $\$ 800,000$ and $\$ 1$ million (courtesy of a Montreal business consultant, construction executive and restauranteur $[\mathrm{sic}]$ ) in the attempt to pull the project off. ${ }^{49}$

Pringle put on his best smile for Adams and declared that the concert "would be one giant party ... with people getting off on people ... really ... people are going to be surprised at how smoothly the thing will go off." 50

The last artist to sign on and fill in the blank was Eddie Money. Born and raised Edward Joseph Mahoney in Brooklyn, he originally trained to be a police officer like his father. However, music took hold of him in the late 1960s. He moved to California and sang with several obscure bands. He emerged as a solo artist in 1977 when he released his first solo album on Columbia Records, simply called Eddie Money, which included a pair of huge radio hits, "Baby Hold On" and "Two Tickets to Paradise." His second album, Life for the Taking, came out in 1978 with two more singles, "Can't Keep a Good Man Down" and "Maybe I'm a Fool." His popularity had plateaued by this point, although that perception was not yet in the air. He also was no stranger to Edmonton audiences: earlier that year he had played two sold-out shows at the Jubilee Auditorium. Opined Graham Hicks: "He is a strong performer, however, his songs have a distressing tendency to sound alike." ${ }^{51}$

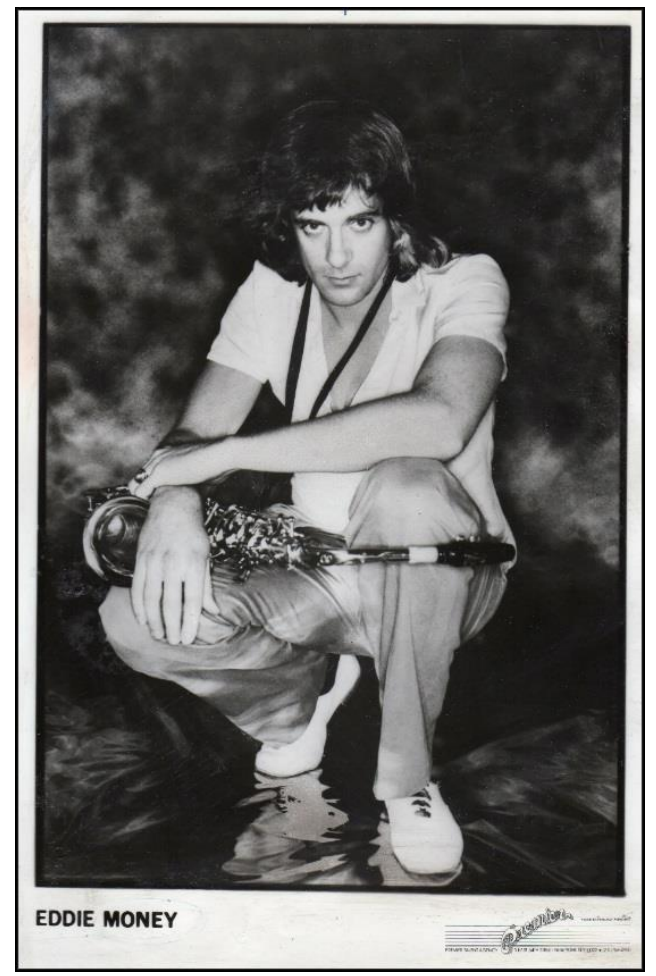

Eddie Money promotional portrait, 1979

Premier Talent Agency

Author's collection

49. James Adams, “James Adams on Television and Radio," Edmonton Journal, August 3, 1979, I-7.

50. Ibid.

51. Graham Hicks, “All Systems Are Go for the Rock and Roll Cirkus," Edmonton Journal, August 22, 1979, G8. 
Melhuish recalls, "We played Eddie Money a lot on The Pringle Program, "Two Tickets to Paradise" and all that stuff. And he was available, and at a good price, and it seemed to make sense. We did some market research in Edmonton, and his records had done very well, so it just seemed to make sense." 52 In addition, he was also represented by Frampton's agency Premier Talent out of New York.

\section{The Preparations}

With the sixth act secured, it seemed like everything was finally coming together. Tom Elsworthy of the Sun wrote on Thursday August 23rd:

For those anticipated 50,000 youth who will pour through those Commonwealth Stadium gates Sunday the show promises to be a quality one. They will be listening to the best sound system and watching the best stage that money can buy. That translates as Bill Graham's FM sound equipment and the Vikon outdoor stage used by such performers as Supertramp in its open air concerts. As Pringle puts it: "We didn't want to come into this size of show and use anything but the very best." Obviously proud of the set-up the talkative promoter added "This is definitely the best sound system ever to hit Edmonton." 53

Elsworthy continued:

So if the weather co-operates and it looks like it will . . . the Cirkus should rock its way over the top in a big way. This is the largest show ever staged by a totally Canadian outfit and confidence is running high. Both Melhuish and Pringle foresee an annual Cirkus-type event. In fact plans are already in the works for next year's show. Names are not available yet, but the stadium will become a future home of any such event. ${ }^{54}$

Not all the problems were revealed to the press. Melhuish recalls with an evil chuckle:

Three days before the show, the trucks arrived with the stage. We could see Hugh Campbell watching from high up in the stadium. The first truck rolled in and sank to its axle as it hit the turf. Not good! We ended up covering the whole field in plywood and a tarpaulin that we had trucked in from Boulder, Colorado. ${ }^{55}$

The staging was constructed by the American company Vikon, who had previously staged numerous outdoor shows: Pontiac Stadium (Detroit), Soldier Field (Chicago), Angel Stadium (Anaheim), the LA Coliseum (Los Angeles) and Gene Hooks Field (Winston-Salem, NC) -all with capacities of 70,000-80,000 people. They knew what they were doing.

52. Martin Melhuish, interview with author, March 20, 2015.

53. Tom Elsworthy, "The Cirkus is Coming," Edmonton Sun, August 23, 1979, 15.

54. Ibid.

55. Martin Melhuish, e-mail message to author, July 16, 2012. 
The stage was set up on top of the two trailers. It measured $60 \times 45 \mathrm{feet}$, and its roof was $60 \times 51$ feet. There were two sound wings each measuring $32 \times 16$ feet, each with two levels. The sound system, all 50 tons of it, did not rest on the stage. Rather it was suspended from the top of the sound wing trusses to project the sound further into the venue. The sound system was provided by FM Productions, the sound and lighting division of Bill Graham Presents, based in San Francisco. It was a multi-million dollar business serving the concert and convention circuits throughout the western United States.

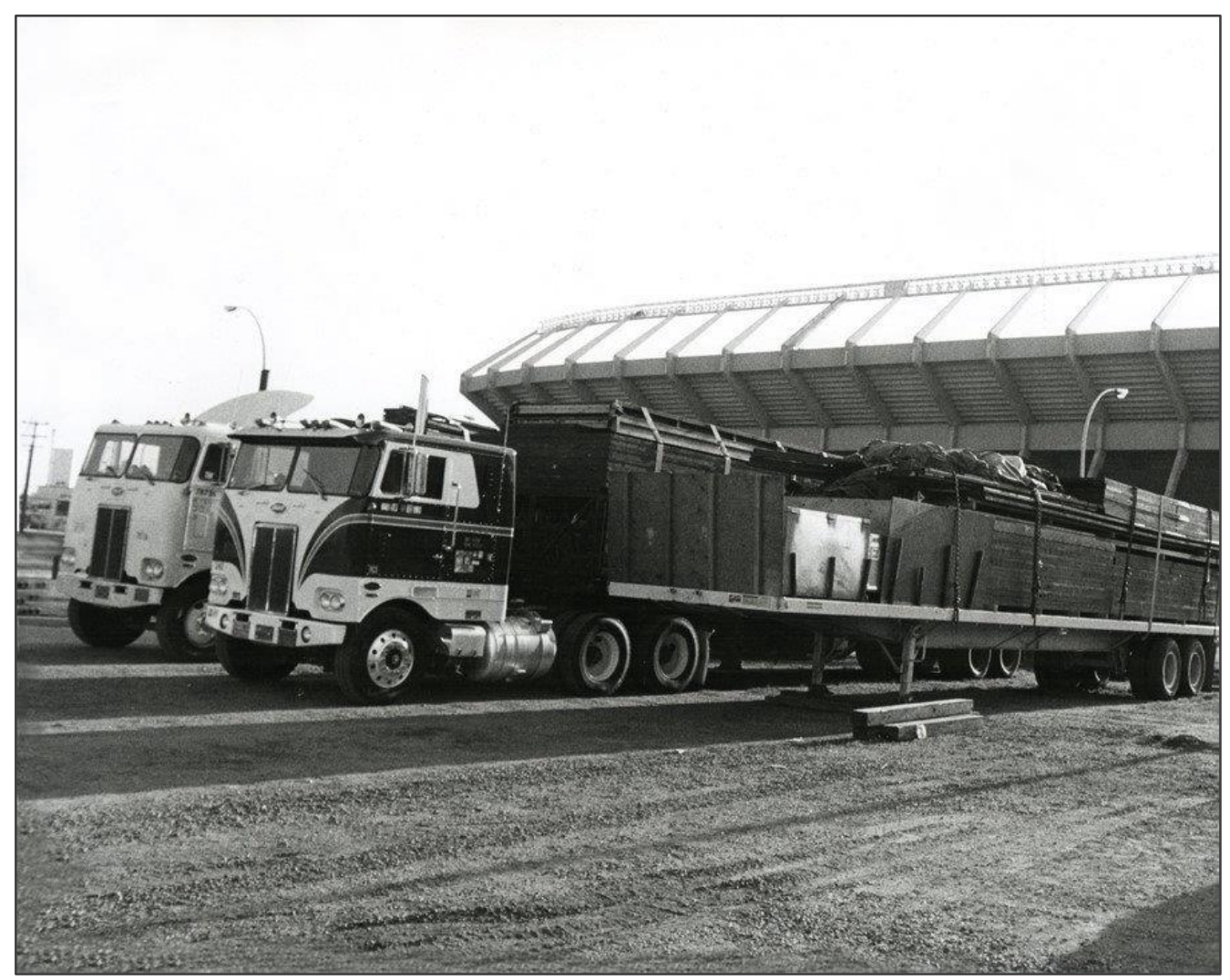

Trucks unloading the stage at Commonwealth Stadium, 25 August 1979

Photo by Marty Melhuish

Courtesy of Martin Melhuish Fonds, Media Commons/University of Toronto

As these logistics were all new to the Lumado partners and there was not enough time to fully learn the ropes, they decided to hire a seasoned stage manager and head of security to oversee all stage activities. The most qualified person in the province was Garth "the Bear" Werschler, who was seconded from Calgary's Brimstone Productions.

Lumado arranged for Ra McGuire and Brian Smith of Trooper to do advance press interviews on August 23rd and 24th. The two talked to print and broadcast journalists from across Canada. For the most part the sessions went well, but it still seemed as if Edmonton reporters preferred to keep the atmosphere negative. McGuire recalls one interview that ended before it began: 
Marty and Doug had set us up in a hotel room and I was doing interviews one after another. One of the interviewers - I believe, but can't confirm, he was from the $\mathrm{CBC}$ - asked me before his interview if, in view of the fact that Frank had recently quit the band, I wanted to talk about Frank during the interview. I thanked him for asking and replied that since he'd given me the option, I'd prefer to not to have to talk about it. So he fires up his tape recorder and his first question is: "So, Ra, before this interview you told me you didn't want to talk about Frank Ludwig - can you tell me why that is?" Marty and Doug (who were both from a radio background) were in the room and they both kinda froze. I spoke slowly into the guy's microphone and said: "You [pause] Fucking [pause] Asshole. It's guys like you that make people not want to do interviews ..." I think he'd scrambled his recorder off before I finished the second sentence. That was the end of that interview! $!^{56}$

The final step prior to the setting up was the printing of a souvenir program. Melhuish and Pringle pulled together an attractive thirty-six page magazine-style publication, black and white with a four-colour cover. Melhuish's constantly positive attitude, his easy availability to the press, and genuine liking for Edmonton won over Graham Hicks. Hicks then assisted them in composing and editing the biographical profiles of the six acts. As he recalls:

Sure, they "won me over" ... Good guys, funny guys, very competitive. . . I I believe we partied together for several years [after that]. They were in it for the music AND to make a living. Oh ya, we became good rock ' $n$ ' roll friends - both were very professional fellas. ${ }^{57}$

Also included in the booklet were group photographs of all the bands, an introduction to Edmonton and its arts scene by Melody Reed, a review of Trooper's greatest hits album Hot Shots by J.J. Linden, and an article on "The New Wave and Beyond" by Roscoe Meltzer.

Security was an issue that took a considerable amount of planning as well as resources. Melhuish shared some, though not all, of the logistics with Journal reporter Linda Goyette several days ahead of the event:

Urbane rock fans may think they're too old for babysitting but not everyone agrees with them. Organizers of the eight-hour Summer Rock Cirkus Sunday have summoned an army of workers 561 to be exact - to keep an eye on the gathering hordes at Commonwealth Stadium. Misbehaving at Edmonton's biggest rock concert to date won't be easy. A special squad of 115 uniformed policemen and an undisclosed number of plainclothes officers have been assigned to the site. The stadium has hired $200 \mathrm{t}$-shirted rugby players, "to create a liaison between the audience and police and to report wrongdoing" according to one stadium staffer. Another 40 people, some security personnel are working for the promoters. The performers, meanwhile, have a crew of 120 or so who will be "keeping an eye on equipment" while attending to other

56. Ra McGuire, e-mail message to author, July 10, 2012.

57. Graham Hicks, e-mail message to author, March 15, 2015. 
duties. Eighty volunteers from St. John's Ambulance will be stationed in three mobile units around the stadium. ... One Commonwealth Stadium staffer described the security precautions as "preparing for the worst but hoping for the best." 58

Finally Inspector Ted Taylor, the "on-site incident commander" for the Edmonton Police Service tried to reassure the public that his officers "won't be looking for a confrontation. . . . the bulk of the people go to a concert to enjoy themselves and not to raise hell. He advised concert-goers to leave liquor and drugs at home and avoid trouble from eagle-eyed policemen at each gate." ${ }^{19}$

The bands were still jockeying for schedule position until the night before the event. Melhuish remembers the "conversations" between the Frampton and Heart reps as a verbal brawl:

The night before the show, there was a major push and pull between the management of Peter Frampton and Heart as to who was going to close the show. When I went to bed that night they were still arguing. That worked itself out as we knew it would. ${ }^{60}$

\section{The Festival}

Finally the day of reckoning arrived. The sun was shining and the temperature started climbing. The Edmonton Sun, being a Sun newspaper, did its usual pandering to the baser instincts and ran a SUNshine Girl in its morning August 26 issue. She was clad in a bikini bottom and an extremely wet Rock Cirkus tshirt accompanied by the caption "Today's SUNshine Girl loves music. Rock on Gordana!" ${ }^{61}$ When it came to selling tickets (and newspapers) any advertising was obviously good advertising.

Frampton's contract explicitly prohibited any filming or taping of the event, so neither broadcasters nor documentarians nor mobile recording studio engineers were present inside the stadium. However, a battery of print reporters, as well as four photographers, were there to capture the happenings. The photojournalists included Gordon Beck of the Edmonton Sun, Keith McNichol of the Edmonton Journal, and two notable independents, Charles Hope of Calgary and Dee Lippingwell of Vancouver.

Unlike many festivals before and after, the Rock Cirkus followed a tight schedule. The Stadium could only be used between $1 \mathrm{pm}$ and $10 \mathrm{pm}$, and accordingly the show started at 1:15 pm. The Dixon House Band started things off. Shauna Oor of the St. Albert Gazette wrote: "The Dixon House Band appeared in electric blue and green apparel on stage. The highlight of their show was their AM song 'Running Scared."'62 Graham Hicks of the Journal liked them:

58. Linda Goyette, “Misbehaving Won't Be Easy at Sunday's Stadium Concert," Edmonton Journal, August 24, 1979, B3.

59. Ibid.

60. Martin Melhuish, e-mail message to author, July 16, 2012.

61. "SUNshine Girl," Edmonton Sun, August 26, 1979, 5.

62. Shauna Oor, "Acoostyx," St. Albert Gazette, August 29, 1979, 37. 
The opening act, the Dixon House Band, showed promise. Leader Edward Dixon House had a memorable song, a dialogue regarding a 10 foot tall woman rocker with her Les Paul plugged into a telephone pole, interspliced with guitar riffs from his guitarist, a slinky woman by the name of Chrissy Shefts. Though plagued by sound problems and an extremely short set, the Vancouver-Seattle band . . . left a good impression. ${ }^{63}$

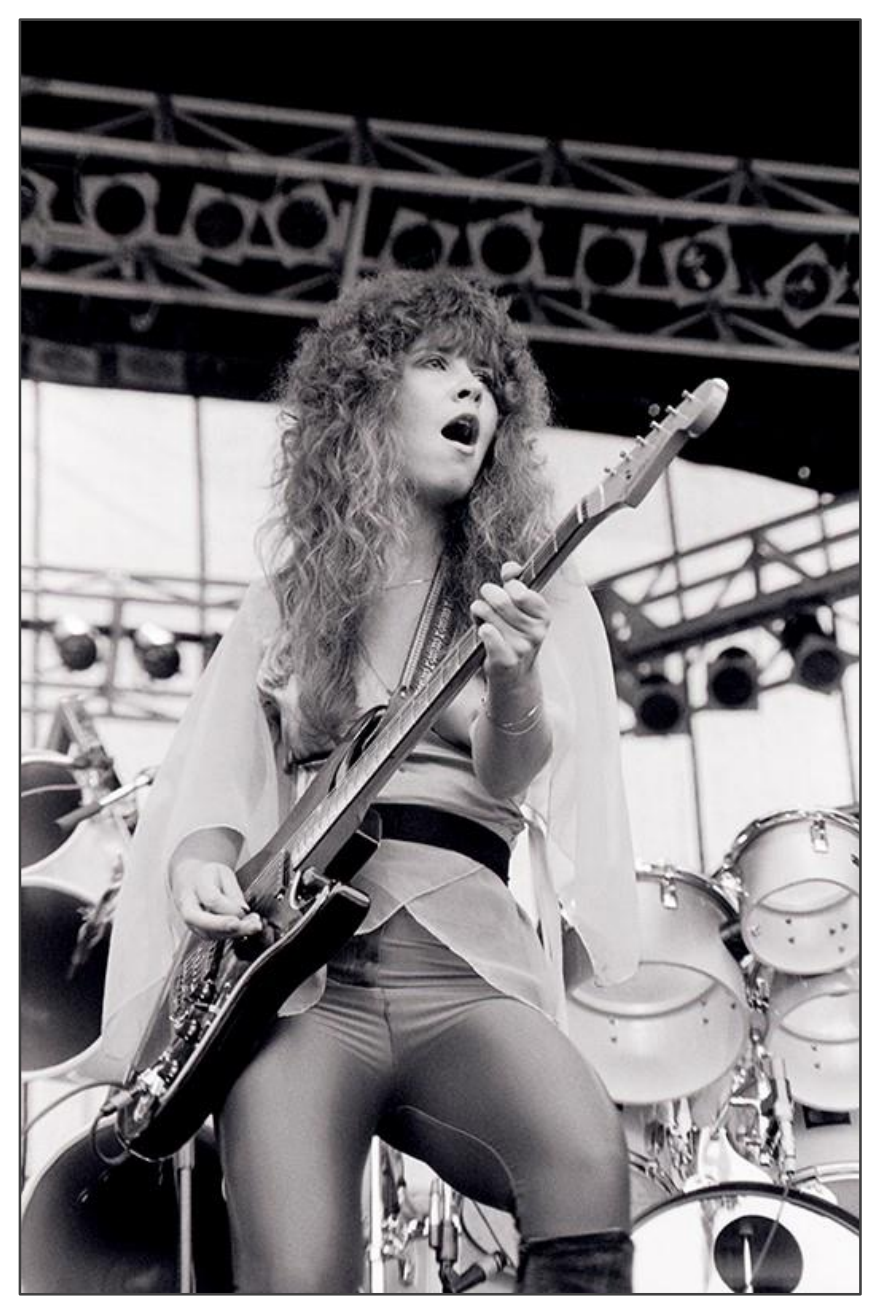

Chrissy Shefts of the Dixon House Band Photo by and courtesy of Charles Hope

Second up, Streetheart roared through their set and easily lived up to its reputation. Oor was impressed:

After an equipment change (the first in a long line) Streetheart took charge. They started off with one of the best songs they do, "Under My Thumb." Kenny Shields was, as always, fast and fine. Streetheart also performed their most recent Top 40 hit "Here Comes the Night" and established themselves as one of the top bands at the concert. ${ }^{64}$

63. Graham Hicks, “Canadian Bands Big Attraction of Sunday's Cirkus,” Edmonton Journal, August 27, 1979, D11.

64. Shauna Oor, “Acoostyx," St. Albert Gazette, August 29, 1979, 37. 


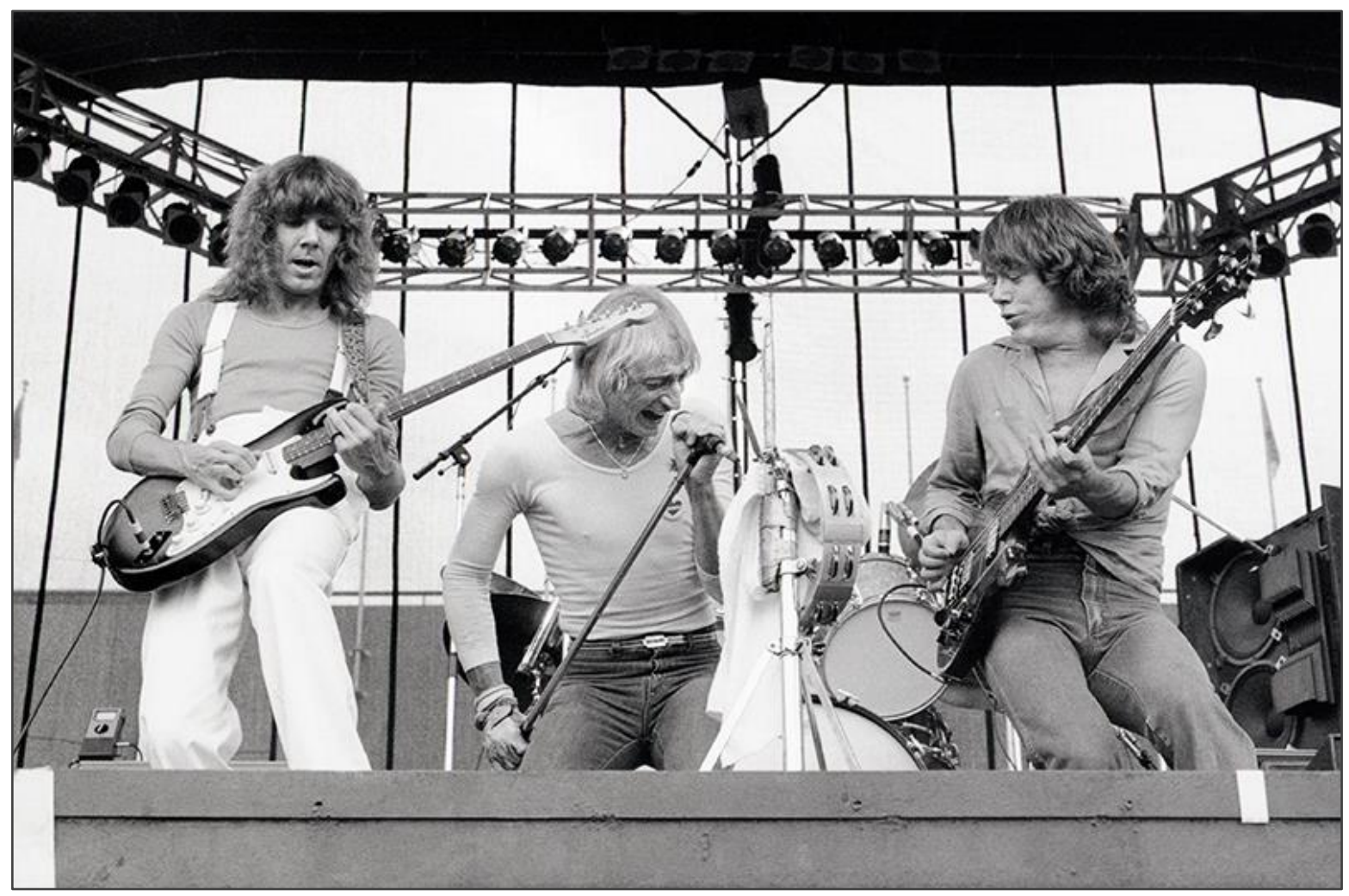

John Hannah, Kenny Shields, and Spider Sinnaeve of Streetheart Photo by and courtesy of Charles Hope

Hicks was generous with his praise:

The day might have been Streetheart's, had the band been given more than a half-hour to play. Months and months of hard touring have moulded Streetheart into a tight performing unit. Kenny Shields, without question, was the best front man of the day. Shields is a dancer, with gliding moves, a liquid grace that coupled with hard-edged prairie-bred rock is a strong combination. The band is saved from becoming yet another hard-rocker by the unique playing of Spider Sinnaeve, a thoroughly creative and original hard rock bassist. Most important Streetheart was having fun. Trooper and Streetheart, with cheerful, fresh, and very positive rock and roll, were more important to the success of Cirkus than any of the other bands. ${ }^{65}$

The third act to appear was the Eddie Money Band, and they turned out to be the sleeper act. Elsworthy of the Sun wrote that "Money in particular fashioned a raw and charged show which brought the audience to their feet. ... an honest performer, Money works hard on stage and gives the crowd plenty to push back against." 66 Oor was also impressed:

65. Graham Hicks, “Canadian Bands Big Attraction of Sunday's Cirkus,” Edmonton Journal, August 27, 1979, D11.

66. Tom Elsworthy, “A Great Bunch of Troopers,” Edmonton Sun, August 27, 1979, 15. 
The Eddie Money band was in top form. The flow between Money and the audience wasn't as evident as it has been in the past, but that's to be expected with such a large and impersonal crowd. The band's back-up vocals have improved immensely since their appearance here last April on ... "Gimme Some Water," the song which, I think, is the best Eddie Money has done yet. $^{67}$

She was not finished:

They began their spot with "Two Tickets to Paradise" and went on to do "Maybe I'm A Fool" during which Money plays the saxophone. They also did "Life For the Taking," "Everybody Rock n' Roll This Place" and "Get a Move On," a fast rock song with an unabashed disco back beat behind it that works incredibly well. ${ }^{68}$

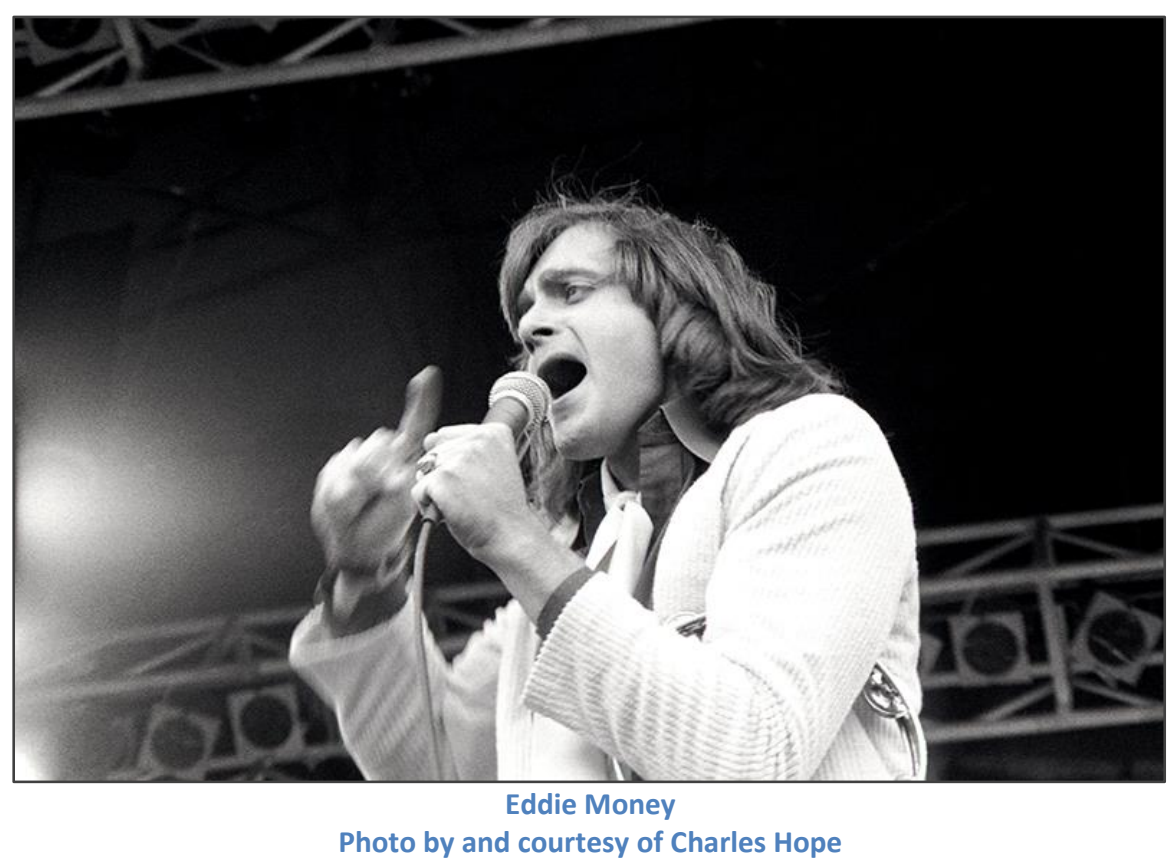

Frampton then stepped up, received a hero's welcome, and proceeded to . . disappoint. Of all bands that day, it was Frampton who came in for the most criticism. There was a notable polarization in the audience. Some thought he was very good. Melhuish for one: "I thought Frampton was good. I mean the guy is a pro and at that point it was just big song after big song in his set. But he's not one who jumps around a lot." ${ }^{\prime 69}$ Bruce Kenyon of K-97 mused: "As much as I like Frampton, he was still doing the Frampton Comes Alive schtick (with the voice box deal in "Do You Feel Like We Do") and I remember him being ... tired sounding." ${ }^{70}$

67. Shauna Oor, “Acoostyx," St. Albert Gazette, August 29, 1979, 37.

68. Ibid.

69. Martin Melhuish, e-mail message to author, July 17, 2012.

70. Bruce Kenyon, e-mail message to author, June 18, 2012. 
His performance was seen to be less than half-hearted by the press. Tom Elsworthy of the Sun wrote a few complimentary comments in the lead-in to his review and then launched into: "Which brings me to the one major disappointment of the program - Peter Frampton. The multi-millionaire rock star appeared merely to be going through the paces. Playing a medley of tunes from his blockbuster album of three years back, Frampton Comes Alive, the blonde singer-guitarist came off as unremarkable."71

Oor also mirrored this:

Peter Frampton and his band should've been billed "the biggest disappointment of the concert." They didn't relate well to the majority of the audience and one got the feeling that the band was both aggravated and bored. The songs were indistinct and ran together. ${ }^{72}$

She continued:

But Frampton proved one thing. Edmontonians are as susceptible to big-name artists hype as everyone else. Frampton can still play the guitar as well as prior to his recent car crash, including songs like "Do You Feel Like I Do" and "Baby I Love Your Way" in his line-up. There was a lot of good guitar work but once Frampton stopped playing, he couldn't be heard in the stands. ${ }^{73}$

Hicks was even more opinionated:

Everybody upstaged Frampton on Sunday - his 90 minutes was the biggest disappointment of the show. As one wag put it, Frampton was a breather between Eddie Money and Trooper. Added another: "A $\$ 100,000$ breather?" Frampton's set consisted of a long stretch of over-loud, dull music, saved by moments of musical beauty in the voice box and guitar work on Do You.

Frampton and his three man rhythm section, plus an occasional four man horn group, were listless, not putting emotion or effort into the first two-thirds of their concert. The best of Frampton's old compositions - Show Me The Way, Something's Happening, Baby I Love You Anyway [sic] - all suffered from lack of interest. ... the sad fact is the man has not written a memorable song since 1976. His new material - horns and all - is dull, without the musical twists and turns that gave Frampton super-star status. "We shouldn't even be paid for that set," one of Frampton's own crew members said to no one in particular. ${ }^{74}$

71. Tom Elsworthy, "A Great Bunch of Troopers," Edmonton Sun, August 27, 1979, 15.

72. Shauna Oor, "Acoostyx," St. Albert Gazette, August 29, 1979, 37.

73. Ibid.

74. Graham Hicks, "Canadian Bands Big Attraction of Sunday's Cirkus," Edmonton Journal, August 27, 1979, D11. 
Even nature was testing people's patience. The late afternoon sun and the heat were at their zenith during Frampton's set. Acres of skin were being baked, and many in the audience were feeling nauseous.

Trooper was next up, and there can be no doubt the band was in top form. Keith Sharp, editor of Music Express, had only superlatives to share: "Trooper was nothing short of amazing. Following a lackluster set by Frampton ... Trooper had the crowd in the palms of their hands. They couldn't have gotten a bigger reception if they'd have trooped out in Edmonton Eskimo uniforms." ${ }^{\prime 75}$ He was still hepped up in his 2014 memoirs:

We then moved closer to the stage to witness what I rate as one of Trooper's best-ever live performances. I think they only played about an hour, but their onstage energy was electrifying. I remember they did "Summertime Blues" and had the whole audience on their collective feet. ${ }^{76}$

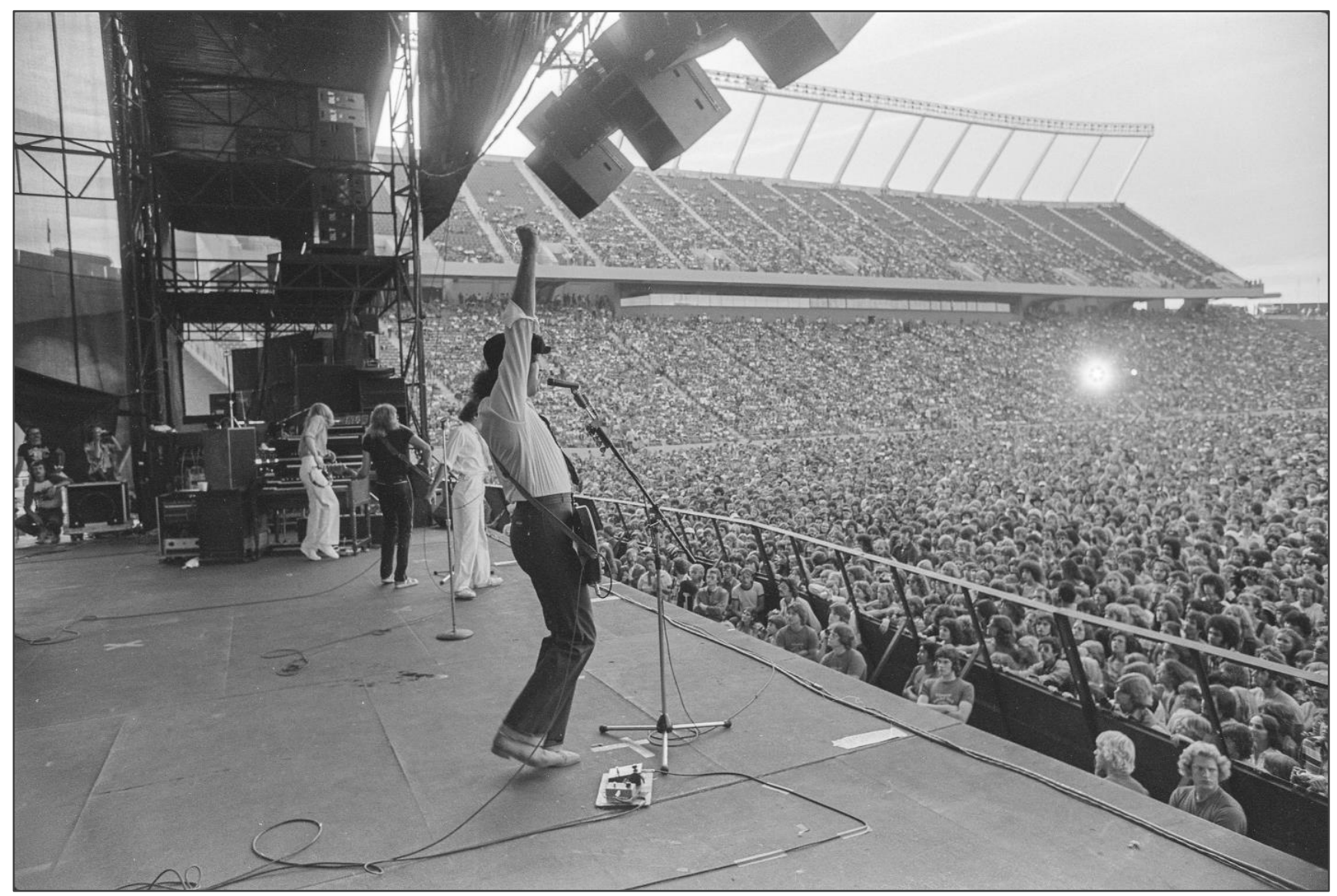

Trooper on stage - "Rock star belts out song", 26 August 1979 Photo by Keith McNichol

Edmonton Journal image J4692/1

Courtesy of Provincial Archives of Alberta

75. Keith Sharp, “Rock Piles," Music Express, September 1979, 3.

76. Keith Sharp, Music Express: The Rise, Fall \& Resurrection of Canada's Music Magazine (Toronto: Dundurn Press, 2014), 36. 
Ra McGuire remembers: "Overall the show felt like one of our very best ever."77 They had the material: "We had a pretty sizeable collection of hits at that point and "The Boys in the Bright White Sportscar" had been a big hit recently - it was released on March 12th of that year - so the set, at 40 minutes, would have been just the biggest hits." ${ }^{78}$

And their slot in the running order turned out to be perfect. Again McGuire:

The audience reaction was overwhelmingly loving and loud. Most everyone, including the press, seems to agree afterwards that we had killed it. As it turned out we ended up with the perfect slot of the event. I'll explain ... both Frampton and Heart wanted what they thought would be the best slot for them. Frampton had decided that he wanted to play "before" us because he wanted the crowd before it was tired out. Heart insisted on the last slot because they had an elaborate light show that wouldn't work in the daylight. So we ended up with Peter Frampton "opening" for us. Frampton had underestimated the crowd's stamina - we totally got the sweet spot, energy size. The crowd was primed and ready when we came on and they went nuts. By the time Heart hit the stage, in the dark, the crowd had finally tired a bit after hot sets. ... So the whole thing worked out great for us! ${ }^{79}$

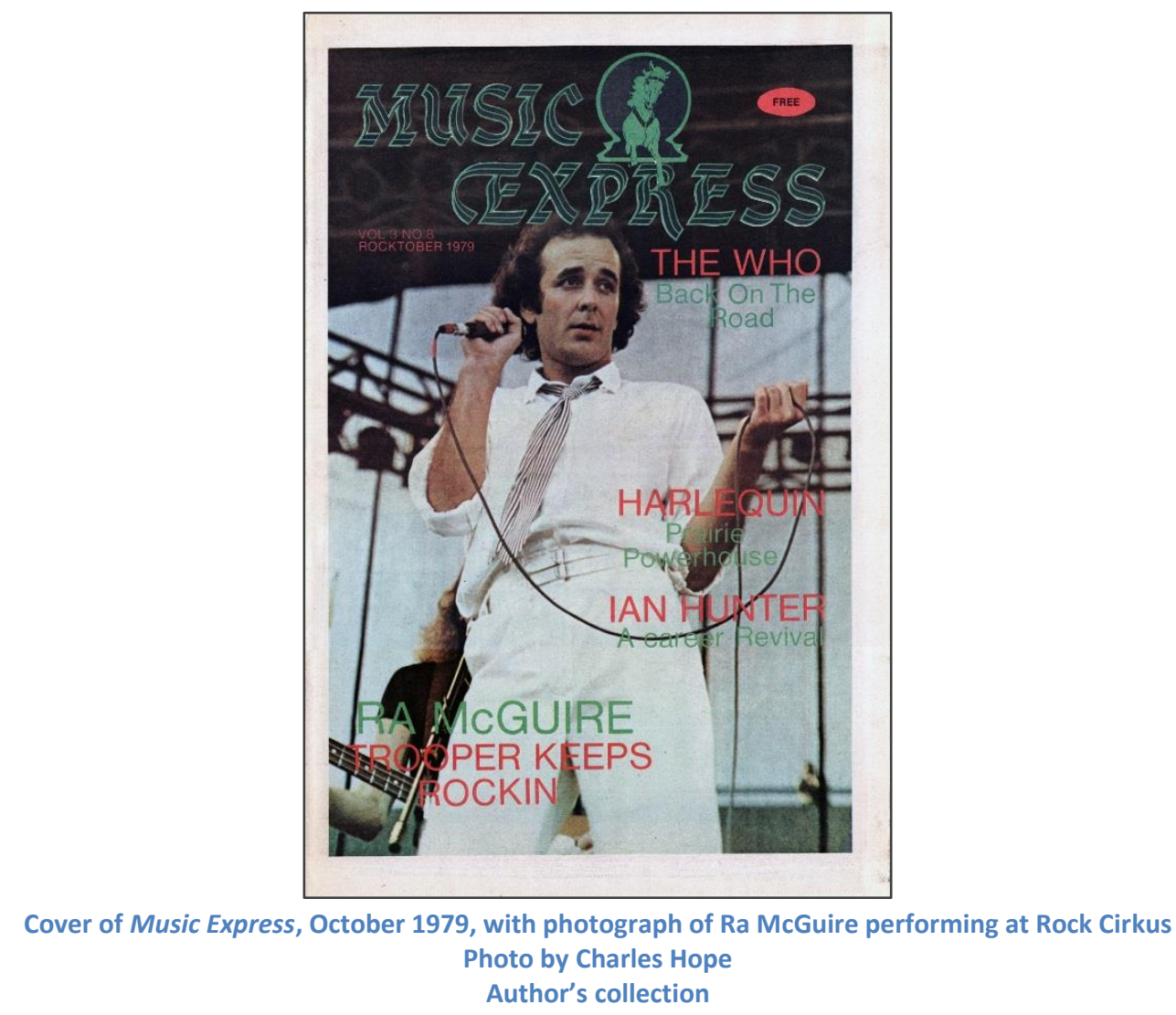

77. Ra McGuire, e-mail message to author, July 10, 2012.

78. Ibid.

79. Ibid. 
Trooper seemed to grab an inordinate amount of press attention. Wrote Hicks:

Trooper, riding high on the greatest hits album, Hot Shots, was the best band of the day. Coming after the sleepy Frampton set, Trooper's cheerful, hard-hitting, pop-rock was as snappy as an unexpected slap, and much more pleasurable. The band zipped through a string of hits as long as your arm - all of which now have renewed life, thanks to Hot Shots - which sold over 100,000 albums in Alberta alone.

At 7:09 p.m., four songs into the set, Cirkus became a party. Suddenly those 40,000 people were clapping, dancing, standing and shaking to Trooper's music. Trooper outdid itself with a cover of The Kink's song, All Day and All of the Night, to be on their new album. The band updated a 60s pop song by pushing it along at triple speed, and adding the driving drums and pulsating bass guitar - Trooper's trademarks. ${ }^{80}$

He also mentioned that it was a different kind of milestone for the band: "There was an extra charm to the evening, as the band was bidding an honourable farewell to keyboard player Frank Ludwig - who is not telling anybody he's about to join ex-Streetheart guitarist Paul Dean . . . in the new Lover Boy band." ${ }^{81}$ Ludwig actually did not tell anyone he was joining Loverboy because-well-he had no intention of joining Loverboy. Instead he would shortly join Randy Bachman in the band Ironhorse.

Contrary to the camaraderie exhibited onstage, it was not a particularly pleasant parting of the ways. McGuire explains:

It was not a comfortable split. We had just struggled through a difficult recording session where Frank had formed a strategic songwriting alliance with Doni and Tommy in order to write a collection of songs to vie with the collection of songs that Smitty and I had written for the album (the first time anything remotely like this this had ever happened) - which they had rehearsed in secret and only presented at our first meeting with our new producer Howard Steele. Smitty and I were gobsmacked. Recording ALL those songs and then determining which would go on the album became a political nightmare. ('Janine' and 'Three Dressed up as a Nine' - ultimately the two hits from the record - were two of the songs the three of them voted against, for instance!)

We finished recording that album on May 15th. Once it was definitely committed to be released, Frank gave his notice (on August 17th) and the Rock Cirkus, as you know, was on the 26th. I think Smitty and I did a good job of keeping up a good front for the Edmonton show. . . It was a bittersweet moment, considering we'd all been rock and roll brothers for five intense years. ${ }^{82}$

\footnotetext{
80. Graham Hicks, “Canadian Bands Big Attraction of Sunday's Cirkus,” Edmonton Journal, August 27, 1979, D11.

81. Ibid.

82. Ra McGuire, e-mail message to author, July 10, 2012.
} 
The moment was made even more bittersweet as MCA president Scott Richards came up on stage and presented the group with a quadruple-platinum award for the Hot Shots album which resulted in thunderous applause and whistling.

The sun was well down on the horizon when the final act took to the stage. It was Heart. While acknowledging the exhausted faces around her, Oor revealed her favouritism:

Heart is the band that made the concert worthwhile. When you take into consideration the heat and fatigue the audience was starting to show the effects of, you really have to marvel at the amount of enthusiasm Heart evoked. ... Heart and the cool night air brought the concert back into full swing. They played in the midst of a tasteful stage show and the band enjoyed themselves, showing sincere appreciation for the crowd's responses. They performed all the classic songs that have made and retained their fame. Songs like "Cook With Fire", "High Time", "Straight On", "Mistral Wind" and "Dog and Butterfly" (off the album of the same name), "Magic Man", "Crazy On You", "Take It Out", "Heartless", "Barracuda" and a few new songs like "Even It Up" off their not-yet-released album were exciting and perfectly executed. And after giving an excellent show, the crowd cheered them on to two well-deserved encores which they performed with all the enthusiasm of a rookie band. ${ }^{83}$

Hicks tried to keep up his enthusiasm for Heart, but made a couple of key observations. Firstly he felt they had succumbed to the over-the-top concert zeitgeist:

Heart gave the day a touch of class, finishing off the rock and roll Cirkus with the flashiest of presentations, fancy costumes, elaborate lighting, fire-bombs, dry-ice, and a series of receding drum risers. In fact the gimmickry detracted from Heart's music. There's a need in Heart to get back to the basics. The performance last night was first-rate, but it hints at becoming too entrenched, becoming increasingly reliant on mechanics, rather than its own incredible musical and performing talent. ${ }^{84}$

He continues:

The talent is there. Only Fleetwood Mac's Stevie Nicks can challenge Ann Wilson as the queen of rock and roll. And Nicks has trouble staying in tune. Wilson's voice last night was nothing short of astonishing. Her dynamics, her power in her upper ranges, her interpretive sensitivity was a joy to hear. The high point of Heart's performance came in the encore, with Ann Wilson going from a high-powered churn-out of Led Zeppelin's Rock and Roll song, to an unparalleled rendition of the Righteous Brothers Unchained Melody. Heart's electricity demands were such that 10 minutes before the concert's end a circuit blew, plunging the stage into darkness and

83. Shauna Oor, "Acoostyx," St. Albert Gazette, August 29, 1979, 37.

84. Graham Hicks, "Canadian Bands Big Attraction of Sunday's Cirkus," Edmonton Journal, August 27, 1979, D11. 
silence. The damage found and corrected, Heart had a chance to play one last song, White Lightning. ${ }^{85}$

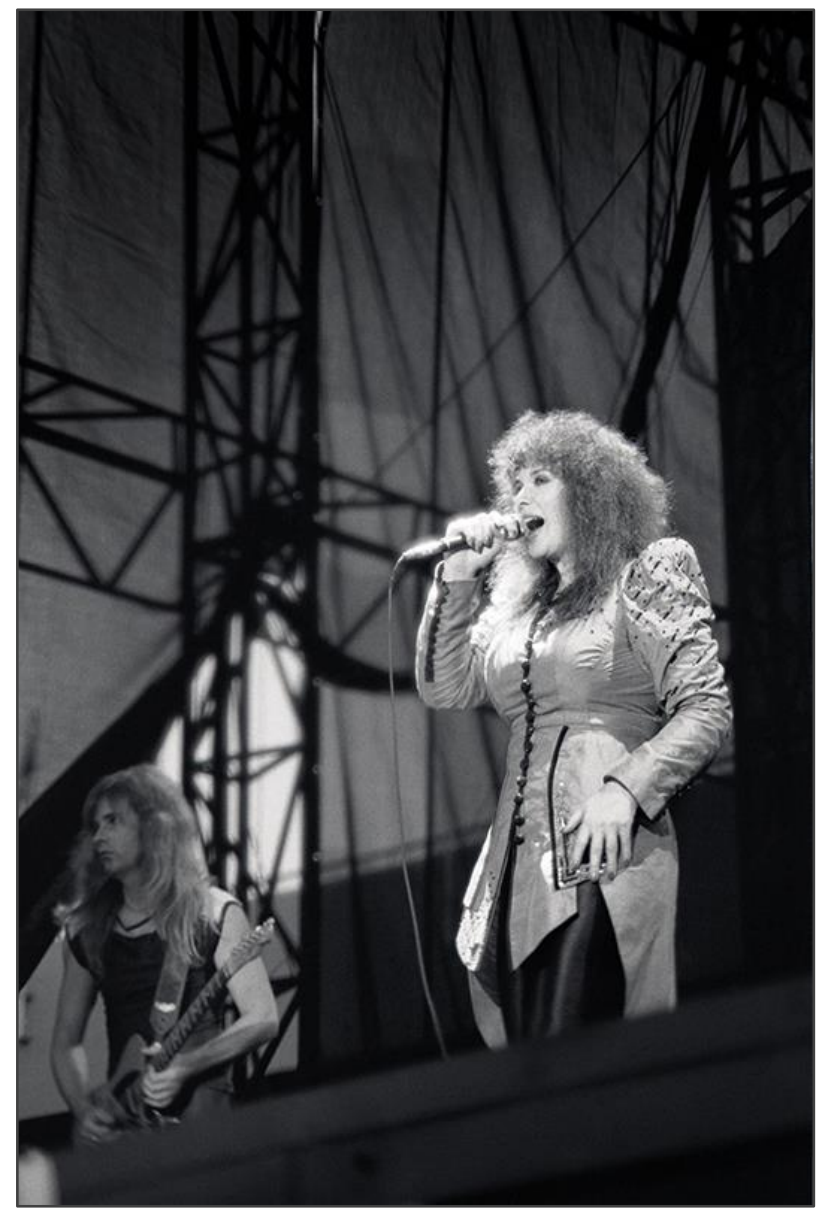

Roger Fisher and Ann Wilson of Heart

Photo by and courtesy of Charles Hope

Secondly Hicks realized that their spot in the lineup affected their reception: "Heart's appearance was subjected not so much to criticism, but rather resignation and acceptance that they did not have the impact they deserved to have. That was not so much because of their performance, but rather because the audience's saturation level." ${ }^{86}$

Elsworthy chimed in: "Not that Heart played poorly. They didn't. However, even with the benefit of a handful of special lighting effects and a fog machine, they couldn't find the groove with an audience which had been listening to music, at this point, for nearly six hours." ${ }^{17}$

The festival thus ended on time, and the audience started departing at $10 \mathrm{pm}$ sharp.

\footnotetext{
85. Graham Hicks, “Canadian Bands Big Attraction of Sunday's Cirkus,” Edmonton Journal, August 27, 1979, D11.

86. Ibid.

87. Tom Elsworthy, “A Great Bunch of Troopers,” Edmonton Sun, August 27, 1979, 15.
} 


\section{The Aftermath}

Press reaction the following day was thoughtful, extensive and naturally mixed. Even the skeptics admitted they had been proved wrong. Generally the concert and the venue were praised. Tom Elsworthy of the Sun: "The first annual K97 Rock Cirkus came to Edmonton yesterday, and judging by the crowd's response and the ease with which this format ran its eight hour course, Commonwealth Stadium cut its concert teeth in fine style." ${ }^{\prime 8}$

All the reporters agreed: as far as rock festivals went, the Rock Cirkus was a success on many levels. It was an exceptionally well-planned and organized public event with efficient and trained security. The crowd was generally orderly and well-behaved. The feared mob violence did not occur. Police were able to keep bottles of alcohol out of the stadium (although some made its way in, injected into oranges). A considerable amount of marijuana was smoked, and smoked openly. The photojournalists were amused and snapped a number of pictures of potheads. The police and security were not amused, but chose to ignore it. One attendee robbed an Edmonton Eskimo souvenir booth with a knife, while twenty drugrelated charges were laid. And, keeping in mind the era, there was a streaker, although clearly not a very well-coordinated one. One article related that "a blonde-haired streaker raced across the field, made an attempted leap at the stage, and hit his head on a steel barricade before being arrested." ${ }^{89}$ There were many sunburns, but no deaths, and only one injury-a young woman crushed at the gates.

The concert left its mark on Commonwealth Stadium-literally. Again Melhuish explains:

The day after the show, I remember running into sports broadcaster Dave Hodge in the lobby of the hotel. Doug and I knew him because we would often run into him at CFRB/CKFM in Toronto where we recorded the Pringle Program. He was laughing because it seems that when they took the plywood, the tarpaulin and the stage off the field, there was now a slight slope in the end zone where the stage had been. We weren't sure if that would turn out to be a hometown advantage for the hometown Eskimos who were about to play the Toronto Argonauts! ${ }^{90}$

Partly through planning, and partly through serendipity, the event brought together a fine blend of 1970s hard and soft rock, straightforward and progressive rock (and coincidentally very radio-friendly) by both Canadian and international talent. The Canadians on the bill not only held their own, they arguably proved themselves better showmen than the British or Americans. The publicity was good for most of the bands involved. Recalls McGuire:

It was a milestone for us in many ways. It was our largest Canadian audience ever up to that point (we'd been on a bill in New Orleans city stadium where we played for 67,000), the highest fee we'd ever got, some of our best reviews, and a real sense that we'd stood shoulder to shoulder with (or, if you believe some of the reviews, had blown off the stage) two

88. Tom Elsworthy, "A Great Bunch of Troopers," Edmonton Sun, August 27, 1979, 15.

89. Chris Dornan, "Fever Pitch Reached at Sound of Music," Edmonton Journal, August 27, 1979, B1.

90. Martin Melhuish, e-mail message to author, November 12, 2016. 
internationally famous acts. Our reviews from the Rock Cirkus show were incredibly useful for us press-wise and our record company took the opportunity to get them around to media everywhere. There were also a few great photos taken. ${ }^{91}$

Oor summed up:

Overall, the K-97 Edmonton Summer Rock Cirkus was a huge success. The weather was nice and Albertans broke a Western Canadian record for an attendance of 42,000 people. Edmonton, I believe, has established itself as THE place for rock musicians to play." ${ }^{12}$

And it did set a record in monetary terms. Variety confirmed this in its September 5 th issue under the headline "Edmonton Rocker Area's Top Grosser":

Edmonton Summer Rock Cirkus, the first outdoor rock music concert held in the one-year-old 55,000-seat Commonwealth Stadium Aug. 26, has become the highest grossing rock show ever held in Western Canada. With 35,000 paying customers at $\$ 20$ a head, the gross was $\$ C 700,000$. ... Lumado Productions, composed of Montreal financier Lucien Richard, and Canadian rock media personalities Doug Pringle and Marty Melhuish, had not staged an outdoor rock concert before. City and stadium officials praised the concert, which ran smoothly and without any hitches. ${ }^{93}$

Not to be overlooked, a profit was made for Lumado, not much, but they were in the black. A next-tofinal accounting sheet dated October 11, 1979 can be found in Melhuish's archive. The total credits include $\$ 678,020$ in ticket sales as well as $\$ 3,655$ of other revenues (t-shirts) for a total of $\$ 681,675 .{ }^{94}$

The expenditures are telling-especially for the talent:

Dixon House Band - $\$ 2,326$

Streetheart $-\$ 17,500$

Eddie Money - $\$ 29,039$

Peter Frampton - $\$ 116,340$

Trooper $-\$ 40,000$

Heart $-\$ 88,000$

For a total of $\$ 293,205$.

91. Ra McGuire, e-mail message to author, July 10, 2012.

92. Shauna Oor, "Acoostyx," St. Albert Gazette, August 29, 1979, 37.

93. "Edmonton Rocker Area's Top Grosser," Variety, September 5, 1979, 98.

94. “Edmonton Cirkus - Etat des resultats au 11 October 1979," Martin Melhuish Fonds, \#2013.005, Media Commons, University of Toronto Library. 
The expenses were outlined:

$$
\begin{aligned}
& \text { Office Expenses }-\$ 5,193 \\
& \text { Hotel/Meals/Drinks - } \$ 21,550 \\
& \text { Publicity - } \$ 26,056 \\
& \text { Mike's Tickets (commission) - } \$ 33,878 \\
& \text { Miscellaneous - } \$ 8,190
\end{aligned}
$$

The stage and sound vendors, professional services, and consultants:

$$
\begin{aligned}
& \text { FM Productions (sound) - } \$ 16,598 \\
& \text { HAL-A-VA }-\$ 27,500 \\
& \text { VIKON (stage) }-\$ 21,000 \\
& \text { Technical Riders }-\$ 26,305 \\
& \text { Transport }-\$ 12,360 \\
& \text { Insurance }-\$ 7,190 \\
& \text { Professional Honoraria }-\$ 21,404
\end{aligned}
$$

Commonwealth Stadium received $\$ 102,366$, and finally Lumado gave themselves $\$ 25,000$. This left a grand total of $\$ 5,279$ profit. ${ }^{95}$ Melhuish chuckles:

The concert came off without a hitch... . The investor, who had shown up with his two young kids in tow, was handed a modest check as profit and was happier than a pig in month-old greens. He had obviously done this for his kids who I'm sure he felt he had not spent enough time with as part of his business life. They got their little satin jackets and got to meet the stars. ... Mission accomplished. ${ }^{96}$

Indeed the fact that they had NOT lost money and had acquired a positive reputation was so unexpected and so encouraging, that the partners tried to repeat their success the following summer. The equilibrium had changed however, and Rock Cirkus II turned out to be a creative and financial disappointment. Again Melhuish:

The following year, 1980, the organization changed. Lucien had a new partner and they reckoned that the talent budget didn't need to be as high as it was. Doug and I vehemently disagreed - we actually had the package of AC/DC and ZZ Top on hold. We decided we would be paid consultants this time around. We booked what we could - given the budget - which included Foreigner, Prism, the lan Hunter Band with Mick Ronson, Warren Zevon, and Toronto. ${ }^{97}$

95. “Edmonton Cirkus - Etat des resultats au 11 October 1979," Martin Melhuish Fonds, \#2013.005, Media Commons, University of Toronto Library.

96. Martin Melhuish, e-mail message to author, July 16, 2012.

97. Martin Melhuish, e-mail message to author, July 17, 2012. 
The company producing was no longer Lumado. This time around it was E.C.I. (Edmonton Cirkus Inc.). Melhuish continues:

There were a number of things that were indicating that this might be a disaster. Instead of the previous year where people were showing up with hundreds and fifties to pay for their tickets, there were a lot of people with small bills and change. It was the start of a rocky patch for the oil-based economy of Alberta. Then it started to rain, and it seemed it rained all that summer. Commonwealth Stadium is an open-air venue and that, literally, put a damper on things. Upshot was, it was a good show, but a lot of money was lost. Even though we personally didn't lose a dime on the experience because of our new status as consultants, Doug and I decided that as far as the business of concert promotion: "been there, done that," and we went back to radio, TV and artist management. ${ }^{98}$

There would be no Rock Cirkus III without Pringle and Melhuish.

While not factually true, most Edmontonians saw the first Rock Cirkus festival as a turning point in their city's reputation for international tours. Prior to this they felt that they could not convincingly play host to an international festival, but afterwards they felt it finally put Edmonton on the touring map for midand top-flight musical acts, both Canadian and international. Mostly though, it demonstrated that Edmonton was fully capable and qualified to stage and support a major rock festival.

Variety confirmed it in November of that year:

Distance is no longer a factor keeping rock bands out of the Alberta market. . . Bands can do the Vancouver - Edmonton - Calgary loop in four days, then swing down the following day to Spokane, Wash. ... Edmonton is no longer looked at as a secondary market. ${ }^{99}$

Commonwealth Stadium secured its status as THE outdoor venue in Western Canada, and would go on to host many more of the notable concerts in Edmonton in the next couple of decades: David Bowie, The Police, Genesis, AC/DC, U2, and The Rolling Stones.

Keith Sharp of Music Express appeared to be impressed with everything: the talent, the scheduling, the weather, the venue, and even the city itself. He exclaimed in his September overview:

As much as Edmonton is maligned by its Calgary neighbor to the south, there's something about the Alberta capital that exudes class when it comes to staging a major event. This first became evident to me last September when, as a member of the Calgary Herald's sports department, I was privileged enough to be assigned to the Commonwealth Games. You had to be there to appreciate just how classy an event that was. So there was a great sense of déjà vu when I found

98. Martin Melhuish, e-mail message to author, July 16, 2012.

99. "Western Can. Rock Promoters Outsail U.S. Counterparts," Variety, November 21, 1979, 98. 
myself back in that same stadium a couple of weeks ago to witness the biggest outdoor rock festival ever to hit these parts. . . . It was possibly the classiest music event I've ever been to. . . . it was almost too good to be true. ${ }^{100}$

Most Edmonton journalists remained reluctant to mention the people chiefly responsible for the festival's success in positive terms. It took an open-minded Calgarian, Keith Sharp, to give credit where credit was due:

Enough can't be said about the organizational talents of promoters Lucien Richard, Doug Pringle and Martin Melhuish - collectively known as Lumado Productions. They and their large staff of organizers ran the entire show like clockwork. . . In a way, the 42,000 people who attended the Rock Cirkus were spoiled. From now on they're going to expect an equally high standard from anyone else that tries to duplicate the Commonwealth Stadium event. Something that other promoters should consider before planning to duplicate the Rock Cirkus." ${ }^{101}$

He summed up his comments with:

The success of Trooper and Streetheart conjours [sic] up the possibility of a true Canada Jam featuring all Canadian groups. Imagine what a tremendous concert could be pulled off with the likes of Trooper, Streetheart, Rush, Triumph, Prism and Max Webster appearing on the same bill. . .. Given enough time and organization, pulling off such a nationalistic showcase is by no means out of the question. ${ }^{102}$

The last word should go to one of the members of the Lumado team as he was interviewed postconcert:

If I had to write a scenario before the Rock and Roll Cirkus began, I couldn't have done better," said the elated but tired copromoter and master of ceremonies Doug Pringle. "I think we've proved. ... It's the start of an era for rock in Edmonton." 103

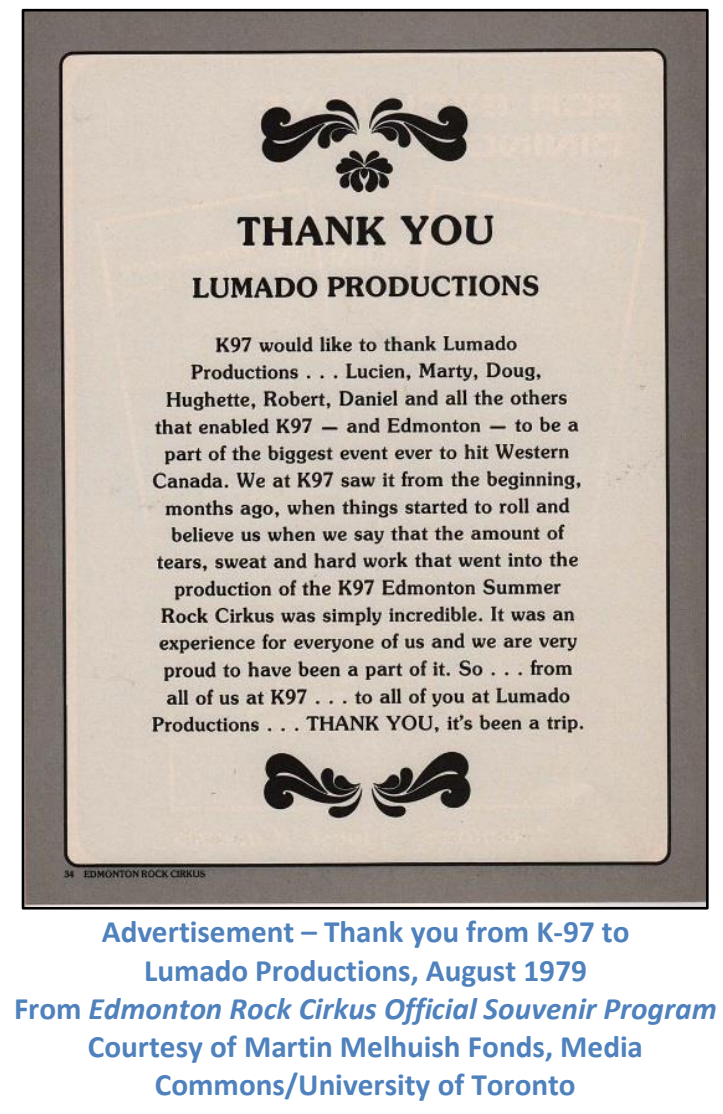

100. Keith Sharp, "Rock Piles," Music Express, September 1979, 3.

101. Ibid.

102. Ibid.

103. Graham Hicks, "Canadian Bands Big Attraction of Sunday's Cirkus," Edmonton Journal, August 27, 1979, D11. 